\title{
Are Biotransformation Studies of Therapeutic Proteins Needed? Scientific Considerations and Technical Challenges
}

\author{
(1) Simone Schadt, (1) Simon Hauri, Filipe Lopes, (1) Martin R. Edelmann, Roland F. Staack, \\ ๑ Roberto Villaseñor, Hubert Kettenberger, Adrian B. Roth, (1) Franz Schuler, \\ (1) Wolfgang F. Richter, and Christoph Funk
}

Roche Pharma Research and Early Development, Pharmaceutical Sciences (S.S., S.H., F.L., R.V., A.B.R., F.S., W.F.R., C.F.) and Roche Pharma Research and Early Development, Therapeutic Modalities (M.R.E.), Roche Innovation Center Basel, F. Hoffmann-La Roche, Basel, Switzerland; and Roche Pharma Research and Early Development, Pharmaceutical Sciences (R.F.S.) and Roche Pharma Research and Early Development, Therapeutic Modalities (H.K.), Roche Innovation Center Munich, Roche Diagnostics, Penzberg, Germany

Received August 15, 2019; accepted October 9, 2019

\begin{abstract}
For therapeutic proteins, the currently established standard development path generally does not foresee biotransformation studies by default because it is well known that the clearance of therapeutic proteins proceeds via degradation to small peptides and individual amino acids. In contrast to small molecules, there is no general need to identify enzymes involved in biotransformation because this information is not relevant for drug-drug interaction assessment and for understanding the clearance of a therapeutic protein. Nevertheless, there are good reasons to embark on biotransformation studies, especially for complex therapeutic proteins. Typical triggers are unexpected rapid clearance, species differences in clearance not following the typical allometric relationship, a mismatch in the pharmacokinetics/ pharmacodynamics (PK/PD) relationship, and the need to understand observed differences between the results of multiple bioanalytical methods (e.g., total vs. target-binding competent antibody concentrations). Early on during compound optimization, knowledge on protein biotransformation may help to design more stable drug candidates with favorable in vivo PK properties. Understanding the biotransformation of
\end{abstract}

a therapeutic protein may also support designing and understanding the bioanalytical assay and ultimately the PK/PD assessment. Especially in cases where biotransformation products are pharmacologically active, quantification and assessment of their contribution to the overall pharmacological effect can be important for establishing a PK/PD relationship and extrapolation to humans. With the increasing number of complex therapeutic protein formats, the need for understanding the biotransformation of therapeutic proteins becomes more urgent. This article provides an overview on biotransformation processes, proteases involved, strategic considerations, regulatory guidelines, literature examples for in vitro and in vivo biotransformation, and technical approaches to study protein biotransformation.

\section{SIGNIFICANCE STATEMENT}

Understanding the biotransformation of complex therapeutic proteins can be crucial for establishing a pharmacokinetic/pharmacodynamic relationship. This article will highlight scientific, strategic, regulatory, and technological features of protein biotransformation.

\section{Introduction}

Over the past years, the number of approved therapeutic proteins has been continuously growing, with currently more than 200 in the United States and the European Union (Walsh, 2018). These approved biotherapeutics span a wide range of recombinant proteins, including the following: clotting factors, thrombolytics, anticoagulants, hormones, growth factors, interferons, interleukins, vaccines, monoclonal antibodies (mAbs) and their derivatives, enzymes, and fusion proteins (Walsh, 2018). Therapeutic proteins are also becoming increasingly

https://doi.org/10.1124/dmd.119.088997 important in terms of revenue: In 2017, seven out of ten best-selling drugs in the United States were therapeutic proteins (https://www. genengnews.com/a-lists/the-top-15-best-selling-drugs-of-2017/). Among them, monoclonal antibodies and their derivatives are steadily gaining importance, both with respect to new approvals and with respect to revenue (Walsh, 2018). Most of these antibody drugs target inflammatory autoimmune diseases and cancer (Walsh, 2018). Currently, IgG molecules represent by far the majority of approved antibody drugs (Walsh, 2018). In addition, there are a few antibody-drug conjugates (ADCs), antibody fragments, and bispecific antibodies. Interestingly, all recently approved monoclonal antibodies were engineered in some way (Walsh, 2018). Engineering serves several purposes,

ABBREVIATIONS: ADC, antibody-drug conjugate; CE, capillary electrophoresis; CMC, chemistry; manufacturing, and controls; CVA, charge variant analysis; DPP4, dipeptidylpeptidase 4; FCRn, neonatal Fc receptor; FT-ICR, Fourier transform ion cyclotron resonance; HPLC, high performance liquid chromatography; HRMS, high resolution mass spectrometry; ICH, International Council for Harmonization; IEX, ion exchange chromatography; LC, liquid chromatography; m/z, mass to charge ratio; mAb, monoclonal antibody; MS, mass spectrometry; NIR, near-infrared; $\mathrm{PD}$, pharmacodynamics PEG polyethylene glycol; PK, pharmacokinetics; R, resolving power; RP, reverse phase; SEC, size exclusion chromatography; ToF, time of flight. 
for example, to humanize the antibody, optimize its pharmacokinetics (PK) profile, increase tumor-specific uptake, increase pharmacological potency, and reduce safety risks. In addition, more and more antibody candidates with next generation formats, as exemplified below, are currently being developed by pharmaceutical companies (Carter and Lazar, 2018). Among them, ADCs are one important therapeutic modality to address oncological diseases aiming for selective delivery of highly potent (and cytotoxic) agents to specific targets (Flygare et al., 2013). ADCs consist of a monoclonal antibody conjugated with a chemotherapeutic agent (payload) through a chemical linker (Beck and Reichert, 2014). Examples for marketed ADCs are brentuximab vedotin (Adcetris), adotrastuzumab emtansine (Kadcyla), and polatuzumab vedotin (Polivy). Another important therapeutic modality are Fcfusion proteins and peptides, for example, etanercept (Enbrel), alefacept (Amevive), Dulaglutide (Trulicity), or Abatacept (Orencia), which have extended half-life in circulation (Beck and Reichert, 2011). Beyond Fcfusion proteins and peptides, various types of antibody formats (e.g., IgG, minibodies, nanobodies, diabodies) can be fused to various cytokines (e.g., interleukins 2, 4, and 12; tumor necrosis factor) (Hutmacher and Neri, 2019). These antibody-cytokine fusion proteins, also known as immunocytokines, circumvent the dose-limiting toxicities often associated with systemic administration of cytokines. Another class of therapeutic proteins that sparks interest within the pharmaceutical industry are bispecific antibodies such as Blinatumomab (Blincyto) and Emicizumab (Hemlibra) (Kontermann and Brinkmann, 2015; Brinkmann and Kontermann, 2017; Labrijn et al., 2019). Bispecific antibodies recognize two different epitopes either on the same or on different antigens. A multitude of different bispecific formats exists, ranging from very small $(50-\mathrm{kDa})$ protein scaffolds (bispecific T-cell engager, dual-affinity retargeting) to relatively big and complex (250-kDa) constructs (Kontermann and Brinkmann, 2015; Brinkmann and Kontermann, 2017; Carter and Lazar, 2018).

Protein biotherapeutics can undergo biotransformation, which we define in this study as a process leading to measurable circulating biotransformed protein that may be active, inactive, or, for example, in the case of ADCs, even potentially toxic (Lee, 2013). Catabolism, in contrast, is defined in this work as degradation of a protein to small peptides and individual amino acids. Metabolism in this manuscript refers to the biotransformation of small-molecule drugs. A typical biotransformation reaction for therapeutic proteins and the main focus of this article is the proteolytic cleavage leading to a truncated protein in circulation. These truncated proteins may be formed by simple cleavage in a defined position that is accessible to a specific protease, or, as is quite often observed for fusion proteins, the biotransformation products in circulation are formed by a multistep process. Initial endopeptidase cleavage may render the protein vulnerable to further exopeptidase processing. The antibody part of a fusion protein is typically stable toward proteolytic biotransformation. Therefore, the observed degradation primarily occurs within the nonantibody part or the linker region. In addition to proteolytic cleavages, glycation (Goetze et al., 2012), deglycosylation (Chen et al., 2009; Alessandri et al., 2012; Qian et al., 2018), deamidation (Liu et al., 2018), oxidation or other amino acid modifications (Liu et al., 2011; Lee, 2013; Hmiel et al., 2015), or, in case of ADCs, payload and linker metabolism may alter the function of therapeutic proteins. An overview of recent biotransformation studies of therapeutic proteins is presented in Table 1, with different types of biotransformation reactions. Because ADC biotransformation is mostly focused on linker cleavage and payload metabolism, which is more similar to small-molecule metabolism than to protein biotransformation, we will not focus on ADC biotransformation in this manuscript. ADC examples are mentioned, however, where they complement the overall context. For ADC biotransformation, the interested reader is referred to some excellent reviews (Saad et al., 2015; Tumey et al., 2015). Whereas proteolytic cleavages are enzyme-catalyzed processes, for example, glycation, deamidation, and oxidation reactions are spontaneous protein degradation processes (Geiger and Clarke, 1987; Wright, 1991; Goetze et al., 2012; Kellie and Karlinsey, 2018). The respective information on biotransformation products, whether pharmacologically inactive or active, is key to support bioanalytical assay development and PK/pharmacodynamics (PD) extrapolations.

\section{Clearance Versus Biotransformation of Therapeutic Proteins}

The clearance of therapeutic proteins ultimately leads to degradation to small peptides and individual amino acids (catabolism). Conventional therapeutic antibodies are predominantly cleared through cellular uptake and proteolytic digestion mechanisms (Fig. 1). These processes happen mainly in endothelial cells and macrophages (Akilesh et al., 2007; Montoyo et al., 2009; Richter et al., 2018; Challa et al., 2019). The first step of this degradation pathway is binding of antibody to the plasma membrane, followed by internalization via fluid-phase endocytosis. Antibody binding can be a specific target-mediated binding, an off-target interaction with internalizing receptors, or a nonspecific interaction with the glycocalyx and/or lipids at the cell surface (Wall and Maack, 1985; Boswell et al., 2010; Leipold and Prabhu, 2019). Following binding, antibodies are internalized through different endocytic pathways that converge in early endosomes, which act as an intracellular sorting compartment. Early endosomes mature to late endosomes, which fuse with lysosomes for proteolytic degradation of the antibodies within their lumen (Huotari and Helenius, 2011; Tarcic and Yarden, 2013). Ultimately, lysosomal catabolism of antibodies typically results in degradation of the proteins to small peptides and amino acids (Hall, 2014). Antibodies can alternatively escape lysosomal degradation by following the neonatal Fc receptor (FcRn) salvage pathway. High-affinity Fc-dependent antibody binding to FcRn occurs only at the slightly acidic $\mathrm{pH}(<6.5)$ in early endosomes. From early endosomes, antibody-receptor complexes are recycled back to the cell surface, where the physiologic $\mathrm{pH}(>7.0)$ of blood triggers antibody release (Roopenian and Akilesh, 2007).

In addition to complete degradation and clearance, protein biotherapeutics may also undergo biotransformation by catalytic cleavage of peptide bonds by proteases, leading to circulating truncated proteins. These truncated proteins might be pharmacologically active or inactive, and their characterization with adequate bioanalytical methods is key for a correct PK/PD assessment. This is predominantly expected for the more complex protein biotherapeutics (e.g., fusion proteins), whereas for most conventional $\mathrm{IgG}$ molecules clearance without formation of detectable biotransformation products is anticipated.

Because very limited knowledge currently exists on the details of proteolytic biotransformation, the next paragraphs are dedicated to a reflection on proteases, tissues, and compartments conceivably involved in these processes.

Proteases represent more than $2 \%$ of the human genome, corresponding to 588 human proteases known to date (Perez-Silva et al., 2016; Kappelhoff et al., 2017). In addition to their involvement in protein degradation, proteases have key physiologic roles in post-translational protein processing. Specifically, they are responsible for the regulation of blood coagulation, fibrinolysis, immune response, complement activation, peptide hormone processing, DNA replication and repair, cell signaling and proliferation, and programmed cell death (Verhamme et al., 2019). Physiologic protease activity is highly regulated to protect endogenous proteins from uncontrolled degradation.

Proteases catalyze the hydrolysis of peptide bonds, either internally (endopeptidases), or terminally (exopeptidases). Exopeptidases that cleave from the $\mathrm{N}$ terminus are aminopeptidases, and those cleaving from the $\mathrm{C}$ terminus are carboxypeptidases. Different catalytic mechanisms have 
TABLE 1

Overview of recent biotransformation studies of therapeutic proteins

\begin{tabular}{|c|c|c|c|c|c|}
\hline Therapeutic Protein Name & Modality & Biotransformation Type & Biologic System & Study Summary and Highlights & Reference \\
\hline $\mathrm{mAb}$ & $\begin{array}{l}\text { Recombinant human } \\
\text { IgG2 mAb }\end{array}$ & Deglycosylation & $\begin{array}{l}\text { In vivo (human) } \\
\text { In vitro } \\
\text { (human serum) }\end{array}$ & $\begin{array}{l}\text { The role of Fc glycans on mAb clearance was } \\
\text { studied in vivo. Similar changes to the glycan } \\
\text { profile were found in vitro after incubation of } \\
\text { the antibody in serum, suggesting that the } \\
\text { changes observed in vivo are due to glycan } \\
\text { cleavage and not differential antibody } \\
\text { clearance. }\end{array}$ & $\begin{array}{l}\text { Chen et al., } \\
2009\end{array}$ \\
\hline $\begin{array}{l}\text { AMG531, AMG195, } \\
\text { AMG195 }\end{array}$ & $\begin{array}{l}\text { Thrombopoietin- } \\
\text { mimetic } \\
\text { peptibodies }\end{array}$ & Proteolytic cleavage & In vivo (rat) & $\begin{array}{l}\text { Biotransformation and stability were studied by } \\
\text { ligand-binding MA (LB-MS) during early } \\
\text { preclinical phase development to guide } \\
\text { immunoassay development, as well as clinical } \\
\text { candidate selection and design. }\end{array}$ & $\begin{array}{l}\text { Hall et al., } \\
\quad 2010\end{array}$ \\
\hline $\begin{array}{l}\mathrm{mAb} 1, \mathrm{mAb} 2 \text {, and } \\
\mathrm{mAb} 3\end{array}$ & $\begin{array}{l}\text { Recombinant human } \\
\text { IgG2 } \mathrm{mAb}\end{array}$ & $\begin{array}{l}\text { N-terminal glutamate to } \\
\text { pyroglutamate conversion }\end{array}$ & In vivo (human) & $\begin{array}{l}\text { Conversion of } \mathrm{N} \text {-terminal glutamate to } \\
\text { pyroglutamate in recombinant mAbs. }\end{array}$ & $\begin{array}{l}\text { Liu et al., } \\
2011\end{array}$ \\
\hline Model mAb & $\begin{array}{l}\text { Recombinant human } \\
\text { IgG2 } 2 \mathrm{mAb}\end{array}$ & C-terminal lysine processing & $\begin{array}{l}\text { In vivo (human) } \\
\text { In vitro } \\
\text { (human serum) }\end{array}$ & $\begin{array}{l}\text { The C-terminal lysine processing of } \\
\text { a recombinant human IgG2 antibody was } \\
\text { studied in vivo and in vitro, to gain insights on } \\
\text { the impact of antibody heterogeneity on drug } \\
\text { safety and efficacy. The analytical } \\
\text { methodology consisted of HRMS preceded by } \\
\text { protein A affinity chromatography and Lys-C } \\
\text { endoproteinase digestion. }\end{array}$ & $\begin{array}{l}\text { Cai et al., } \\
2011\end{array}$ \\
\hline $\mathrm{mAbA}, \mathrm{mAbB}, \mathrm{mAbC}$ & $\begin{array}{l}\text { Recombinant human } \\
\text { IgG mAbs }\end{array}$ & Glycation & $\begin{array}{l}\text { In vivo (human) } \\
\text { In vitro } \\
\text { (human serum) }\end{array}$ & $\begin{array}{l}\text { In vitro and in vivo glycation was studied by LC- } \\
\text { MS }\end{array}$ & $\begin{array}{l}\text { Goetze et al., } \\
2012\end{array}$ \\
\hline $\mathrm{mAb} 1$ & $\begin{array}{l}\text { Recombinant human } \\
\text { IgG1 mAb }\end{array}$ & Deglycosylation & $\begin{array}{l}\text { In vitro (human } \\
\text { serum) }\end{array}$ & $\begin{array}{l}\text { The role of Fc glycans on clearance of mAb1was } \\
\text { studied in vivo. In addition, in vitro } \\
\text { experiments to study high mannose species } \\
\text { (M6 and M7) were conducted. These were } \\
\text { cleaved in serum, and cleavage could be } \\
\text { blocked with a mannosidase I inhibitor. }\end{array}$ & $\begin{array}{l}\text { Alessandri } \\
\text { et al., } 2012\end{array}$ \\
\hline $\mathrm{mAb} 1, \mathrm{mAb} 2$ & $\begin{array}{l}\text { Recombinant human } \\
\text { IgG1 mAbs }\end{array}$ & Glycation & $\begin{array}{l}\text { In vivo (mouse) } \\
\text { In vitro } \\
\text { (mouse serum) }\end{array}$ & $\begin{array}{l}\text { Homogeneous antibodies bearing the Man5 } \\
\text { glycoform were produced and in vivo PK in } \\
\text { mouse was studied. A mouse serum } \\
\text { mannosidase was identified that converted } \\
\text { most Man8/9 to Man6. }\end{array}$ & $\begin{array}{l}\text { Yu et al., } \\
2012\end{array}$ \\
\hline $\begin{array}{l}\text { Fc-FGF21 WT } \\
\text { [1-424], Fc-FGF21 } \\
\text { RG [1-424] }\end{array}$ & $\begin{array}{l}\text { Fc-fibroblast growth } \\
\text { factor } 21 \text { (FGF21) } \\
\text { fusion proteins }\end{array}$ & Proteolytic cleavage & $\begin{array}{l}\text { In vivo } \\
\text { (Cynomolgus } \\
\text { monkey) }\end{array}$ & $\begin{array}{l}\text { Differential ELISA was combined with LB-MS } \\
\text { to study the proteolytic cleavage sites of Fc- } \\
\text { FGF21 fusion proteins; the approach was } \\
\text { applied for compound optimization. }\end{array}$ & $\begin{array}{l}\text { Hager et al., } \\
2013\end{array}$ \\
\hline MAB2 & Human IgG1 mAb & $\begin{array}{l}\text { Deamidation, N-terminal } \\
\text { glutamate to pyroglutamate } \\
\text { conversion, oxidation }\end{array}$ & In vivo (human) & $\begin{array}{l}\text { Multiple quality attributes of a therapeutic } \\
\text { antibody were recovered from in-life samples. }\end{array}$ & Li et al., 2016 \\
\hline $\begin{array}{l}\text { Trastuzumab } \\
\text { (Herceptin) }\end{array}$ & $\mathrm{ADC}$ & Deamidation & $\begin{array}{l}\text { In vivo (human; } \\
\text { patients) }\end{array}$ & $\begin{array}{l}\text { Trastuzumab biotransformation by deamidation } \\
\text { of asparagine and isomerization of aspartic } \\
\text { acid in different complementarity-determining } \\
\text { region peptides has a significant impact on LB- } \\
\text { MS assay results. Strikingly, the degree of } \\
\text { biotransformation appeared to vary across } \\
\text { patients. }\end{array}$ & $\begin{array}{l}\text { Bults et al., } \\
\text { 2016; Liu } \\
\text { et al., } 2018\end{array}$ \\
\hline $\begin{array}{l}\text { Tetranectin/ } \\
\text { apolipoprotein A1 }\end{array}$ & Fusion protein & Proteolytic cleavage & $\begin{array}{l}\text { In vivo (rabbit) In } \\
\text { vitro (RPTEC/ } \\
\text { TERT1) }\end{array}$ & $\begin{array}{l}\text { Biotransformation of tetranectin/apolipoprotein } \\
\text { A1 was studied by LB-MS. A major and } \\
\text { pharmacologically active biotransformation } \\
\text { product was identified, formed by N-terminal } \\
\text { truncation of alanine and proline. This } \\
\text { biotransformation is catalyzed by DPP4, as } \\
\text { shown by in vitro investigations in RPTEC/ } \\
\text { TERT1 and incubations with DPP4. }\end{array}$ & $\begin{array}{l}\text { Zell et al., } \\
\text { 2016; } \\
\text { Schadt } \\
\text { et al., } 2019\end{array}$ \\
\hline NTs-huFc & $\begin{array}{l}\text { Neurotensin-huFC } \\
(\mathrm{NTs}-\mathrm{huFc}) \text { fusion } \\
\text { protein }\end{array}$ & Proteolytic cleavage & $\begin{array}{l}\text { In vitro (mouse } \\
\text { serum) }\end{array}$ & $\begin{array}{l}\text { Biotransformation of NTs-huFc protein was } \\
\text { studied using a novel bottom-up targeted } \\
\text { protein workflow based on on-bead } \\
\text { succinimidyloxycarbonylmethyl tri-(2,4,6- } \\
\text { trimethoxyphenyl) } \mathrm{N} \text { terminus tagging. }\end{array}$ & $\begin{array}{l}\text { Kullolli et al., } \\
2017\end{array}$ \\
\hline
\end{tabular}


TABLE 1-Continued

\begin{tabular}{|c|c|c|c|c|c|}
\hline Therapeutic Protein Name & Modality & Biotransformation Type & Biologic System & Study Summary and Highlights & Reference \\
\hline Dulaglutide & $\begin{array}{l}\text { Glucagon-like } \\
\text { peptide } 1 \text { (GLP1)- } \\
\text { Fc fusion protein }\end{array}$ & Proteolytic cleavage & In vivo (mouse) & $\begin{array}{l}\text { A novel HRMS approach for analyzing large } \\
\text { molecule proteins at the intact level in biologic } \\
\text { samples without digestion. This consisted of an } \\
\text { immunoaffinity capture combined with a LC- } \\
\text { HRMS method to quantify the intact parent } \\
\text { molecule while simultaneously identifying } \\
\text { biotransformation products for recombinant } \\
\text { fusion proteins. Two proteolytic sites within } \\
\text { the GLP1 peptide sequence of dulaglutide } \\
\text { were identified using this approach. The } \\
\text { findings facilitated further critical designing } \\
\text { and screening of novel protein therapeutic } \\
\text { candidates and understanding of their } \\
\text { pharmacokinetics and pharmacodynamics. }\end{array}$ & $\begin{array}{l}\text { Kang et al., } \\
2017\end{array}$ \\
\hline $\begin{array}{l}\text { Anti-CD22 MC-vc- } \\
\text { PAB tubulysin M } \\
\text { TDC variants } \\
\text { (tubulysin TDC1 } \\
\text { and TDC2) }\end{array}$ & $\mathrm{ADC}$ & $\begin{array}{l}\text { Payload biotransformation, } \\
\text { glycation, cysteine adducts, } \\
\text { glutathione adducts, }\end{array}$ & $\begin{array}{l}\text { In vivo (mouse, } \\
\text { rat) }\end{array}$ & $\begin{array}{l}\text { Biotransformations of multiple site-specific } \\
\text { THIOMAB antibody-drug conjugates (TDCs) } \\
\text { were studied by HRMS. }\end{array}$ & He et al., 2017 \\
\hline $\begin{array}{l}\text { Fc-FGF21 WT Fc- } \\
\text { FGF21 RG }\end{array}$ & $\begin{array}{l}\text { Fc- FGF21 fusion } \\
\text { proteins }\end{array}$ & Proteolytic cleavage & In vivo (mouse) & $\begin{array}{l}\text { Biotransformations of a wild-type Fc-FGF21 } \\
\text { construct and a sequence re-engineered Fc- } \\
\text { FGF21 construct were studied by } \\
\text { immunoaffinity capture coupled with CE-MS. }\end{array}$ & $\begin{array}{l}\text { Han et al., } \\
2017\end{array}$ \\
\hline $\begin{array}{l}\text { Model therapeutic } \\
\text { mAb }\end{array}$ & Human mAb & Oxidation & In vitro & $\begin{array}{l}\text { An untargeted LC-HRMS--based method } \\
\text { supported by bioinformatics tools for } \\
\text { differential analysis allowing for rapid } \\
\text { identification of modified peptides derived } \\
\text { from the biotransformation of therapeutic } \\
\text { proteins. A human antibody was forced } \\
\text { oxidized and compared with an untreated } \\
\text { control using a bottom-up proteomics } \\
\text { workflow. }\end{array}$ & $\begin{array}{l}\text { Yao et al., } \\
2018\end{array}$ \\
\hline $\begin{array}{c}\text { Fc-FGF21 (PF- } \\
06645849)\end{array}$ & $\begin{array}{l}\text { Fc-FGF21 fusion } \\
\text { protein }\end{array}$ & Proteolytic cleavage & $\begin{array}{l}\text { In vivo (rat) In } \\
\text { vitro (rat } \\
\text { serum) }\end{array}$ & $\begin{array}{l}\text { Intact protein LC-MS and digestion LC-MS/MS } \\
\text { methods were combined to characterize the } \\
\text { biotransformation of Fc-FGF21 and to quantify } \\
\text { the intact molecule and its major } \\
\text { biotransformation products. }\end{array}$ & Li et al., 2019 \\
\hline
\end{tabular}

evolved for peptide hydrolysis by exploiting specific residue-mediated chemical reactions in their active sites. Accordingly, proteases can be classified as serine, threonine-, cysteine- aspartyl-, glutamyl-, and metallopeptidases (Brix, 2013). These include intracellular and extracellular proteases, cytosolic, endosomal/lysosomal, and membraneassociated proteases.

An overview on various peptidases and proteases occurring in human blood, liver, and kidney, including their cleavage specificity, was compiled by Werle and Bernkop-Schnürch (2006). One example of a protease that has been described to be involved in biotransformation of therapeutic proteins is dipeptidylpeptidase 4 (DPP4; exopeptidase 3.4.14.5) (Zell et al., 2016). DPP4 is expressed in endothelial cells of different organs, including kidney, liver, and the capillary endothelium, and is also present as a soluble form in circulation (Deacon, 2004). DPP4 cleaves dipeptides with the N-terminal structure Xaa-Pro-Xaa or XaaAla-Xaa (Mentlein, 1999). Prominent endogenous peptide substrates for DPP4 are the incretin hormones glucose-dependent insulinotropic polypeptide and glucagon-like peptide-1 (GLP1). DPP4 plays an important role in the regulation of both peptides and inactivates them by $\mathrm{N}$-terminal cleavage. Both glucose-dependent insulinotropic polypeptide and glucagon-like peptide-1 have a very short apparent plasma half-life of 7 minutes and 1 to 2 minutes, respectively (Deacon, 2004). More recently, DPP4 has also been shown to catalyze biotransformation of the fusion protein tetranectin-apolipoprotein A1 (Zell et al., 2016; Schadt et al., 2019).

The localization of the proteases responsible for the formation of circulating biotransformation products of therapeutic proteins has not been investigated in a systematic way, and hardly any literature examples exist. Therefore, we believe that some theoretical considerations might be helpful and also spark discussion among scientists who are active in this field. Following administration, a therapeutic protein may be biotransformed by proteases at the injection site (for subcutaneous administration), during absorption, in the lymphatic system, and in the circulatory system (Wang et al., 2012). From the circulation, therapeutic proteins then cross the vascular wall to reach the site of action in the target tissue, either by diffusion across discontinuous capillaries or via transcellular transport. Biotransformation might also occur by endothelial cells of different organs, and, because endothelial cells are directly in contact with blood and lymph, this might result in a circulating biotransformation product. Although the protein drug may be subject to biotransformation by the target tissue as well, a transfer back to blood circulation via the lymph is required to yield a circulating biotransformation product.

Moving from tissue level to cellular level, the most likely location for proteases contributing to the formation of circulating biotransformation products is the extracellular space, and the proteases are either soluble (e.g., in blood and lymph) or membrane-associated (Werle and BernkopSchnurch, 2006). In the case of intracellular proteases, additional transport processes are required for the formation of circulating biotransformation products: the protein therapeutic needs to be taken up by the cell, and the product needs to be transferred back out of the cell. The most likely intracellular location for generation of circulating biotransformation products are early endosomes, where limited proteolytic cleavage might occur. For enzymes such as cathepsins, activity is observed already at the slightly acidic $\mathrm{pH}$ found in early endosomes (Brix et al., 2008; Sanman et al., 2016). From early endosomes, biotransformed $\mathrm{Fc}$-containing protein therapeutics may be released into blood by $\mathrm{FcRn}$ recycling. Late endo-lysosomes are less likely to 
contribute to biotransformation because proteolysis is more pronounced and leads to degradation to small peptides and amino acids. Cytosolic proteases and the proteasome also seem less likely to be key contributors to the generation of circulating metabolites because this requires a transfer from the endosome into the cytosol and back. For the same reason, mitochondria, endoplasmic reticulum, Golgi apparatus, and the nucleus seem to be very unlikely locations for proteases contributing significantly to the formation of circulating biotransformation products. However, under disease conditions, for example, in tumor tissue or in a state of inflammation, proteases might be mislocalized outside of their original compartments, abnormally expressed in cells or the extracellular space, or not sufficiently regulated anymore. Thus, they might contribute to formation of circulating biotransformation products.

\section{Strategic Considerations}

In this section, we will compare strategic approaches for biotransformation studies for small-molecule drug candidates and for therapeutic proteins. Although for therapeutic protein drugs biotransformation mainly means cleavage of the peptide bond by proteases, smallmolecule drug biotransformation is mainly mediated by cytochrome P450 and various phase II enzymes such as glucuronosyl or sulfo transferases. For small-molecule drugs, strategies and approaches to assess biotransformation are well established (Schadt et al., 2018), and regulatory guidance for the assessment of metabolites is provided by the FDA (2016) and ICH (2010). Well-defined packages of studies are conducted throughout the discovery and development phases (Fig. 2). Typically, during lead identification and lead optimization, metabolite identification is conducted to identify metabolic soft spots. The main in vitro metabolites are identified by high resolution mass spectrometry (HRMS), often as Markush structures, to guide chemists toward more stable compounds. Later, once a candidate drug has been identified, further more detailed in vitro studies are conducted to enable entry into humans. A typical approach would be incubation of the drug candidate with liver microsomes and cryopreserved hepatocytes from human and animal species selected for safety assessment. Metabolites are identified by HRMS and compared across species. In some cases, definitive metabolite structures are elucidated by NMR spectroscopy. The in vitro metabolite profiles are then further compared with in vivo animal plasma metabolite profiles to establish a qualitative in vitro-in vivo correlation (even though there are several limitations). At the same time, the major enzymes responsible for the biotransformation are identified, both for the assessment of the clearance of the compound and for drug-drug interaction assessment. During phase 1, human plasma from single and/or multiple ascending dose studies is screened for metabolites. Human relevant metabolites exceeding $10 \%$ of drug-related material in circulation are identified, and metabolite exposure at steady state at the anticipated therapeutic dose level is assessed in comparison with metabolite exposure in animals (maximum tolerated dose group) to assure human safety (Schadt et al., 2018). The human drug metabolism package is complemented with the human radiolabel absorption/ distribution/metabolism/excretion study, which is typically conducted during phase 2 . The human radiolabel absorption/distribution/metabolism/excretion study provides all details on the fate of a new drug candidate: Which metabolites and what amounts are circulating, how is the compound excreted, via feces or via urine, as parent compound or as metabolites?

In contrast, for therapeutic proteins biotransformation studies are not conducted by default because the clearance of therapeutic proteins is generally understood. As described above, clearance is typically via degradation to small peptides and individual amino acids. Also, there is no general need to identify the enzymes involved in biotransformation as there is for small molecules, as this information is not relevant for drug-drug interaction assessment and for understanding the clearance of a therapeutic protein.

Nevertheless, understanding the biotransformation of a therapeutic protein can be important for various reasons and at various stages during discovery and development (Fig. 2). During compound optimization, early knowledge about biotransformation may help to design more stable drug candidates with favorable in vivo PK properties (Hager et al., 2013). Vulnerable positions in the molecule can be identified, and the protein can subsequently be re-engineered to replace labile motives with

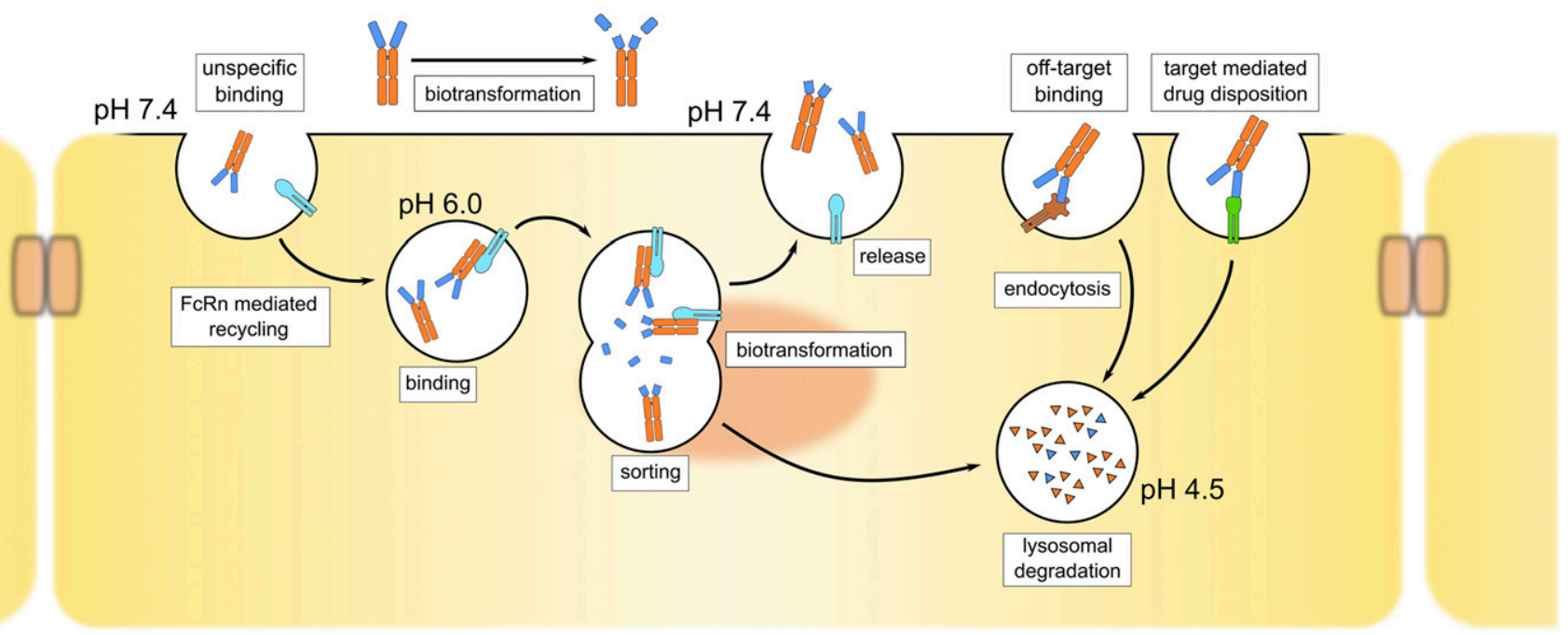

Fig. 1. Overview on cellular clearance and biotransformation processes in endothelial cells and hematopoietic cells (primarily macrophages). 
A

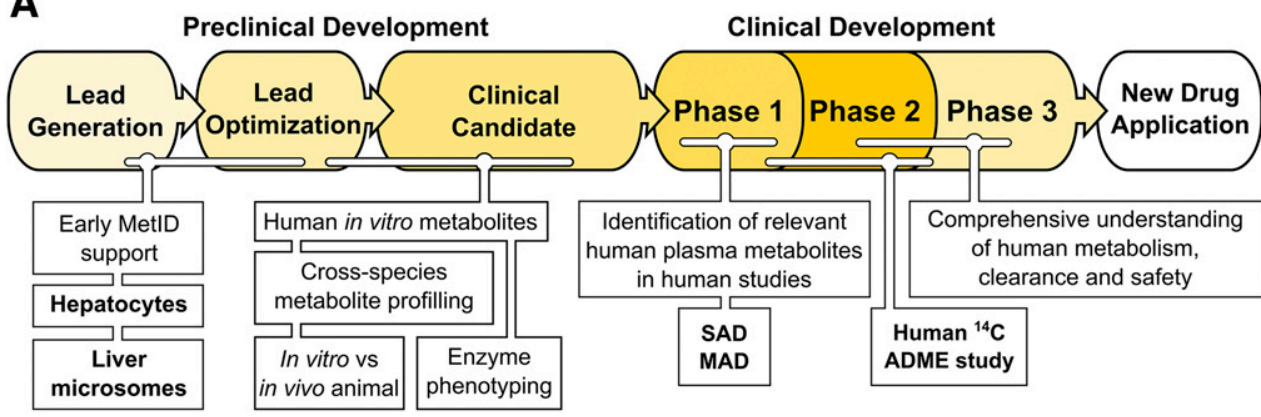

B

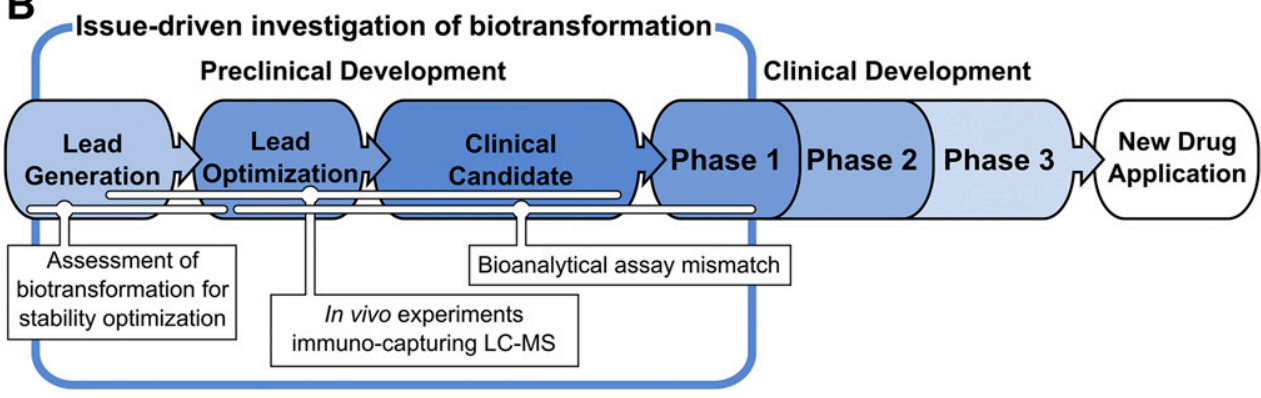

Fig. 2. (A) Small-molecule metabolite identification (MetID) packages across drug discovery and development. (B) Biotransformation characterization support for therapeutic proteins. more stable ones. A typical trigger to embark on biotransformation studies would be an unexpected PK behavior in preclinical species (Fig. 3A). This could either be due to fast clearance from circulation or due to biotransformation, and might impact the active drug exposure. In such cases, the features of the bioanalytical method (total drug assay, active drug assay, intact drug assay for multidomain biologics) already provide first information. Depending on the bioanalytical method, potential biotransformation issues of the molecule might or might not become apparent (Heinrich et al., 2015). A fast clearance of a therapeutic protein, measured by a total drug assay, indicates that the compound is truly cleared from the circulation. A fast clearance of a therapeutic protein, measured by an active drug assay, does not necessarily mean rapid clearance of the compound from circulation, but might also indicate a biotransformation step leading to the formation of inactive truncated proteins. The combination of different bioanalytical methods might help to better understand whether loss of active exposure is due to clearance or biotransformation impacting the activity (total drug assay and active drug assay). In case of multidomain compounds, the use of different assays targeting different domains of the compound might also provide first information to confine the biotransformation site.

Athough the bioanalytical strategy can be key to identify potential biotransformation issues early on, likewise biotransformation information can be highly important to design and select appropriate bioanalytical methods. This very close mutual dependency between both disciplines becomes particularly obvious in two scenarios that may lead to a mismatch between the exposure data and the observed PD: 1) When only total drug bioanalytical methods are available, active molecules and truncated, inactive biotransformation products cannot be distinguished, and the PD is lower than might be expected from the PK curve (Fig. 3B). 2) When biotransformation occurs at the binding site of an assay reagent and thus the truncated but active molecules escape from being detected, the PD is higher than might be expected from the PK curve (Fig. 3C). Available information on protein biotransformation can guide the reagent selection as well as assay format selection. Depending on the desired information, reagents that detect an epitope prone to biotransformation might be avoided or explicitly selected. A combination of different bioanalytical methods might be necessary to fully characterize the $\mathrm{PK} / \mathrm{PD}$ of a therapeutic protein in such cases, especially if the biotransformation products are pharmacologically active. Depending on the contribution to the overall pharmacological effect, active biotransformation product(s) must also be included in the protection of the intellectual property of the drug product. In summary, typical triggers for biotransformation studies are unexpected rapid clearance, species differences in clearance not following the typical allometric relationship, a mismatch in the PK/PD relationship, and the need to understand observed differences between the results of multiple bioanalytical methods.

The early use of predictive in vitro systems would be the ideal approach to identify and prioritize the most promising candidates. Replacing animal experiments by in vitro experiments for compound optimization is highly desirable from a $3 R$ (replace, reduce, refine) perspective. In addition, having a human in vitro system that mimics potential human in vivo biotransformation early on clearly is an advantage. Simple systems such as human plasma or serum are suitable to study processes like deamidation, glycation, C-terminal lysine processing, $\mathrm{N}$-terminal glutamate to pyroglutamate conversion, and, in case the relevant proteases are present, also proteolytic cleavage. Case examples can be found in Table 1. Notably, almost all in vitro studies that have been published to date were conducted in serum or plasma (see Table 1). In many cases, however, plasma or serum does not contain the relevant proteases responsible for the biotransformation of therapeutic proteins. The same is true for subcellular fractions of liver tissue or other organs. Therefore, in vitro models like cellular or microphysiological systems would be key to allow the assessment of human biotransformation of therapeutic proteins early on in drug research and development. In our experience, in vitro biotransformation studies with therapeutic proteins using cellular systems are experimentally challenging, and this is most likely the reason why only few studies have been reported to date (Schadt et al., 2019). The low in vitro biotransformation rate by cells, combined with the much lower ratio of cell number per reaction volume in vitro compared with the in vivo situation, significantly limits the application of 

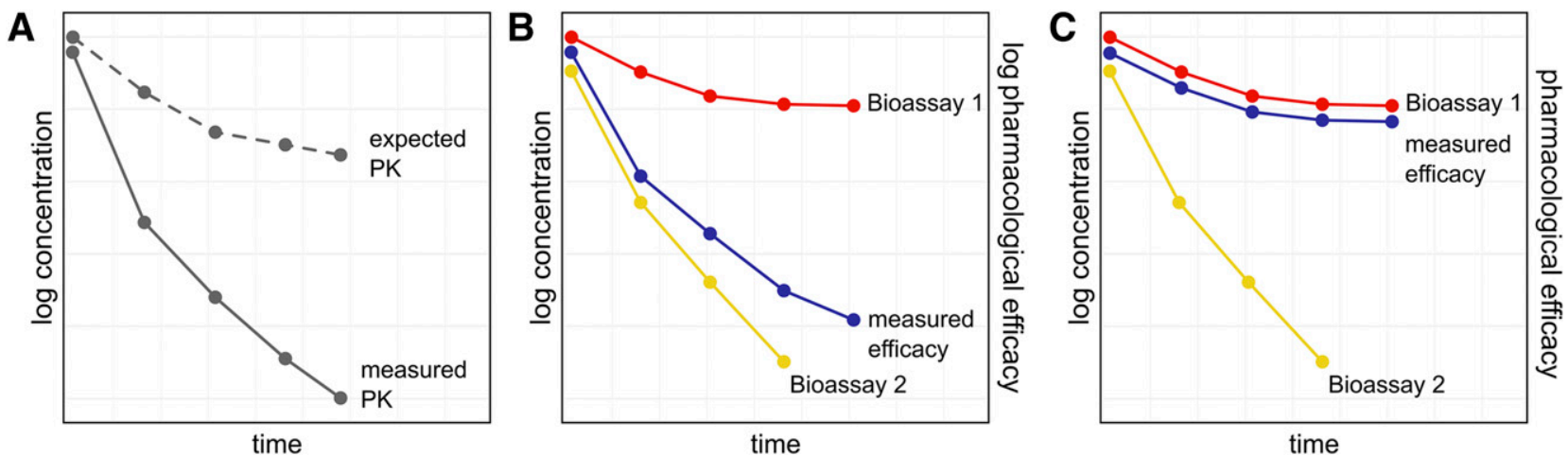

Fig. 3. Exemplified triggers to embark on biotransformation studies: unexpected rapid clearance (A) or a mismatch in different bioanalytical assays (e.g., total vs. targetbinding competent therapeutic protein concentrations), with biotransformation products that may contribute to the pharmacological effect (B) or not (C).

cellular in vitro biotransformation studies of therapeutic proteins. To illustrate this, the human body contains $6.2 \times 10^{11}$ endothelial cells (Sender et al., 2016), with a reaction volume of 51 blood. In comparison, in a cell culture in a 24 -well plate, $2.4 \times 10^{5}$ endothelial cells (https://www.thermofisher.com/ch/en/home/references/gibcocell-culture-basics/cell-culture-protocols/cell-culture-useful-numbers. html) are incubated in $0.3 \mathrm{ml}$ medium. This corresponds to a difference of two orders of magnitude.

\section{Regulatory Considerations}

Several regulatory guidance documents exist that make recommendations on biotransformation studies for biotherapeutics. The main guidance on preclinical studies is International Council for Harmonization (ICH) S6 (R1) "Preclinical Safety Evaluation of BiotechnologyDerived Pharmaceuticals" (ICH, 2012), which was adopted in 2012 and states, "The expected consequence of metabolism of biotechnologyderived pharmaceuticals is the degradation to small peptides and individual amino acids. Therefore, the metabolic pathways are generally understood. Classical biotransformation studies as performed for pharmaceuticals are not needed. Understanding the behaviour of the biopharmaceutical in the biologic matrix (e.g., plasma, serum, cerebral spinal fluid) and the possible influence of binding proteins is important for understanding the pharmacodynamic effect."

Similarly, the World Health Organization "Guidelines on the Quality, Safety, and Efficacy of Biotherapeutic Protein Products Prepared by Recombinant DNA Technology" adopted in 2013 states the following: "The expected consequence of metabolism of recombinant DNAderived biotherapeutics is degradation to small peptides and individual amino acids. Therefore, the metabolic pathways are generally understood. Classic biotransformation studies, as performed for pharmaceuticals, are not needed" (WHO, 2013). This reflects the common view that biotherapeutics may have a very limited potential to form biotransformation/degradation products with unexpected off-target activity and contrasts the situation with small-molecule drugs. The latter have several guidance documents on how to identify potential safety risks associated with metabolites and degradation products, for example, the Food and Drug Administration Guidance for Industry, Safety Testing of Drug Metabolites (FDA, 2016).

Still, biotransformation studies may be warranted to understand the disposition and PD of biotherapeutics in specific cases as mentioned in ICH S6 (R1). This is also reflected in the European Medicines Agency "Guideline on the Clinical Investigation of the Pharmacokinetics of Therapeutic Proteins," which is effective since 2007. It recommends to evaluate and discuss the need for in vitro metabolism studies: "The need for, and the feasibility of, specific studies of the route of elimination and metabolism (e.g., microsomal, whole cell or tissue homogenate studies) and identification of metabolites in vitro should be considered and discussed on a case-by-case basis." This guideline further recommends quantifying metabolites with PD activity if this is feasible (EMA, 2007).

ADCs are a therapeutic modality combining a biotherapeutic with a small molecule. Currently, five ADCs are clinically approved and used in oncology indications [trastuzumab emtansine (Kadcyla), brentuximab vedotin (Adcetris), inotuzumab ozagamicin (Besponsa), gemtuzumab ozagamicin (Mylotarg), and polatuzumab vedotin (Polivy)]. All five approved ADCs contain small-molecule cytotoxic agents linked to monoclonal antibodies specifically targeting surface proteins on cancer cells. Many more ADCs are in clinical development. The metabolic evaluation of ADCs is covered in ICH S9, "Nonclinical Evaluation of Anticancer Pharmaceuticals," adopted in 2009 stating, "Conjugated products are pharmaceuticals covalently bound to carrier molecules, such as proteins, lipids, or sugars. The safety of the conjugated material is the primary concern. The safety of the unconjugated material, including the linker used, can have a more limited evaluation. Stability of the conjugate in the test species and human plasma should be provided. A toxicokinetic evaluation should assess both the conjugated and the unconjugated compound after administration of the conjugated material" (ICH, 2009). Regulatory filing applications of approved ADC drugs do show that the kinetics of the conjugated and unconjugated drugs are followed in preclinical species and clinical studies, and the release of the cytotoxic moiety from the conjugated drug is investigated in vitro in cell culture systems and in plasma. The metabolic fate of the unconjugated cytotoxic drug alone was studied in in vitro systems; see, for example, the European Medicines Agency assessment report for Adcetris (Adcetris EPAR).

In summary, several health authority guidelines exist on the expected biotransformation studies for biotherapeutics. The main focus may lay on the mechanistic understanding of PD as biotherapeutics bear a limited risk of off-target safety issues based on metabolites formed in patients. ADCs may be studied in more detail to enable a mechanistic understanding of release of the pharmacologically active cytotoxic drug.

\section{Technical Approaches To Study Therapeutic Protein Biotransformation}

A typical experimental approach to study the biotransformation of therapeutic proteins in our laboratories is based on the following experimental sequence: In an ideal case, the therapeutic protein of interest is radiolabeled (described in more details below). Using radiolabeled proteins is not absolutely essential, but it provides a significant advantage because this offers the opportunity to ensure complete recovery during multiple sample preparation steps. Then the 
animal experiment is conducted with the labeled protein. Serum and tissue samples are subjected to immunoaffinity purification (potentially with domain-specific ELISA assays), which will be detailed below. Recoveries of all sample preparation steps are monitored via the radioactive label. The immunoaffinity-purified protein can then be subjected to different analytical methods. All require some kind of separation first; therefore, we dedicate one section to the topic of separation. A typical first experiment is radio high performance liquid chromatography (HPLC), as described below, to get a quick overview on any biotransformation steps that lead to a significant shift in retention time. More detailed analysis and identification of biotransformation products can be achieved by mass spectrometry (MS), which is described in the corresponding section. The final section of this chapter is dedicated to chemical derivatization methods in the context of biotransformation.

\section{Radiolabeling and Orthogonal Labeling Approaches}

The ability to differentiate material related to therapeutic protein from proteins in the biologic matrix is a key requirement to characterize a biotransformation profile. A prominent method that became standard in small-molecule drug metabolism studies is labeling with radioactive isotopes. However, due to practical considerations, the radiolabeling of large molecules differs from established labeling strategies developed for small molecules. Biotherapeutics are usually expressed in cell culture systems. To provide radioactive-labeled amino acids to be incorporated into the therapeutic protein would require the growth medium to contain high levels of radiation and result in a large amount of liquid radioactive waste. The far more practical approach is the postsynthesis labeling of amino acid side chains. There are several methods broadly used to label therapeutic proteins with radionuclides. One of the main methods of radiolabeling proteins is the direct introduction of radioactive atoms to functional groups without the use of chemical spacers. An alternative procedure to the direct method is the conjugation of bifunctional chelating agents, which are able to complex metallic radionuclides, or preradiolabeled small molecules containing a reactive group for coupling to proteins. Key points to consider for the labeling strategy and the choice of label type are the retention of the affinity to cellspecific receptors, the binding to biologic targets, and the PK properties.

${ }^{14} \mathrm{C}$ is preferred for a biotransformation study of small molecules, but the specific activity is too low to be used for a corresponding protein study (Table 2). Based on the relatively short half-lives of metallic radionuclides, the use of these isotopes is limited for protein biotransformation studies. Therefore, an alternative nuclide must be chosen for a large-molecule biotransformation study. Traditionally, ${ }^{125} \mathrm{I}$ has been used for protein labeling. Direct protein labeling with ${ }^{125} \mathrm{I}$ on tyrosyl or histidyl residues is performed by sodium or potassium iodide and an oxidizer like chloramine-T (Greenwood et al., 1963) or Iodo-Gen (Fraker and Speck, 1978) through electrophilic substitution for hydrogen

TABLE 2

List of common nuclides for biologic assays

\begin{tabular}{lccc}
\hline Nuclide & Decay Mode & Half-Life & Specific Activity \\
\hline${ }^{3} \mathrm{H}$ & $\beta^{-}$ & $12.3 \mathrm{yr}$ & $1.1 \mathrm{TBq} / \mathrm{mmol}$ \\
${ }^{14} \mathrm{C}$ & $\beta^{-}$ & $5730 \mathrm{yr}$ & $2.3 \mathrm{GBq} / \mathrm{mmol}$ \\
${ }^{125} \mathrm{I}$ & $\mathrm{EC}^{a}$ & $60 \mathrm{~d}$ & $80.5 \mathrm{GBq} / \mathrm{mmol}$ \\
${ }^{131} \mathrm{I}$ & $\beta^{-}, \gamma$ & $8 \mathrm{~d}$ & $242.4 \mathrm{TBq} / \mathrm{mmol}$ \\
${ }^{99} \mathrm{~m} \mathrm{Tc}$ & $\mathrm{IT}^{b}$ & $6 \mathrm{~h}$ & $19.3 \mathrm{TBq} / \mathrm{mmol}$ \\
${ }^{111} \mathrm{In}$ & $\mathrm{EC}^{a}$ & $2.8 \mathrm{~d}$ & $13.5 \mathrm{GBq} / \mathrm{mmol}$ \\
${ }^{89} \mathrm{Zr}$ & $\beta^{+}$ & $78 \mathrm{~d}$ & $16.9 \mathrm{TBq} / \mathrm{mmol}$ \\
\hline
\end{tabular}

${ }^{a}$ Electron capture.

${ }^{b}$ Isomeric transition. in the target protein (Hermanson, 2013). A mild oxidation can be induced by lactoperoxidase in the presence of hydrogen peroxide (Morrison, 1980). However, oxidation can damage proteins, and IgG is especially vulnerable: two surface-exposed methionines are located in the FcRn binding site of IgGs that are sensitive to oxidation (Stracke et al., 2014). Consequently, the affinity to the cellular FcRn is lower, which leads to an impact on PK properties of the antibody (Cymer et al., 2017; Edelmann et al., 2019).

An alternative to direct iodination was described by Bolton and Hunter (1973) as indirect iodination. To avoid oxidation in presence of proteins, a small molecule may be first radioiodinated and, in a second step, conjugated with amine- or thiol-containing proteins, for example, lysine or cysteine residues, to perform a covalent bond modification. A detailed review of both direct as well as indirect radioiodination with different types of activated small molecules has been reported by Wilbur (1992). However, the use of $\gamma$-emitting radioiodine requires special equipment and laboratory facilities in terms of radiosafety. Nevertheless, a major issue and biohazard of radioiodinated proteins is in vivo dehalogenation induced by the enzyme deiodase (Amartey et al., 2005). This loss of the label leads to increased uptake of radioiodine in the thyroid gland (Vaidyanathan and Zalutsky, 1990).

More recently, tritium-labeled proteins have been used in biotransformation studies to circumvent the disadvantages of radioiodination biotransformation studies. Tritium belongs to the class of long-lived isotopes with a half-life of 12.3 years and is the $\beta$-emitting radioactive isotope of hydrogen. Several methods for incorporating tritium into proteins are known. Solid-state palladium-catalyzed hydrogen/tritium exchange at $80^{\circ} \mathrm{C}$ (Zolotarev et al., 1995) bears the risk of denaturation of the protein. Tack et al. (1980) reported protein tritium labeling by sodium $\left[{ }^{3} \mathrm{H}\right]$ borohydride-induced reductive methylation at lysine residues. Conjugation of a tritium-prelabeled small molecule analogous to the Bolton-Hunter method, as previously discussed, is certainly an option for a fast, efficient, and safe access to tritium-labeled proteins. Small molecules, like maleimides, able to conjugate with cysteine residues of proteins (Hempel, 1963), are one option for labeling. Because disulfides do not react with maleimides, disulfides need to be reduced prior to the conjugation. This reduction may damage the protein. Muller (1980) reported a protein labeling with $N$-succinimidyl $\left[2,3-{ }^{3} \mathrm{H}\right]$ propionate in 1980 at lysine residues. Two years later, Kummer (1986) transferred this technique to label monoclonal antibodies. $N$-succinimidyl $\left[2,3-{ }^{3} \mathrm{H}\right]$ propionate reacts with $\varepsilon$-amino groups in lysine residues and $N$-terminal $\alpha$-amines in proteins in $\mathrm{pH}$ range 7.0-8.5 at room temperature in 15 minutes to 1 hour. A covalent amide bond formation ensures a label-stable protein for subsequent in vivo studies (Jaramillo et al., 2017).

As an alternative to radiolabeling, therapeutic proteins can also be labeled with near-infrared (NIR) or fluorescence dyes. A variety of different dyes is commercially available, for example, Biotum's CF series or LI-COR IRDye CW series for NIR applications. Numerous dyes from the Alexa Fluor family (Thermo Fisher Scientific) cover the near-UV up to the NIR emission spectrum. NIR labeling is cost effective and requires no specialized equipment or radiation safety protection. However, antibody modifications with dyes may result in a change of the protein's physicochemical properties. Depending on the degree of labeling, the fluorophore conjugation may impact antibody plasma clearance and tissue distribution (Conner et al., 2014; Cilliers et al., 2017).

\section{Affinity Purification}

MS is an ideal tool to characterize the heterogeneity of therapeutic proteins and has long been established as a routine technology in the 
chemistry, manufacturing, and controls (CMC) field for drug substance/ drug product release testing. These studies may also provide important hints to potential biotransformation hot spots. Furthermore, the similar analytical strategies and learnings are transferable to the development of methods for biotransformation studies. The difference between CMC characterization and biotransformation studies, however, is the required sensitivity and specificity. CMC analysis is performed on highly concentrated samples in buffer solution compared with the biotransformation studies that have to deal with low concentrations of drug in a complex biologic background. Consequently, the greatest challenge to enable the application of these MS-based methods to biologic samples and to allow a comparable level of structural characterization as well as identification of potential biotransformation is an appropriate enrichment of the analyte. In the field of quantitative bioanalysis, the use of so-called hybrid methods has significantly improved the sensitivity (Duggan, 2018). In this study, an immunoaffinity extraction of the analyte is employed to selectively enrich and clean up the analyte from the biologic sample matrix, prior to liquid chromatography (LC)-MS analysis.

Although bioanalysis and biotransformation studies have many similarities with regard to appropriate sample enrichment, there are several special demands for biotransformation analysis that need to be taken into consideration. In both cases, therapeutic proteins need to be analyzed from biologic or clinical samples that harbor an inherent molecular complexity. Blood plasma, for example, represents a very protein-rich environment with concentrations ranging from a few picograms to milligrams per milliliter (Hortin and Sviridov, 2010). Depending on the therapeutic protein dose, the final plasma concentration is in the nanograms per milliliter to micrograms per milliliter range. If subtle changes to the molecule through biotransformation occur, the limit of detection is often reached. For bioanalytical purposes, ligand-binding assays are still the gold standard, particularly due to their unprecedented sensitivity. MS analysis for bioanalytical purposes is typically performed after enzymatic digestion with monitoring/quantitation of defined signature peptides by selected reaction monitoring (Wei et al., 2018), even though the use of intact protein analysis via HRMS is now gaining popularity (van den Broek and van Dongen, 2015; Jin et al., 2018; Qiu et al., 2018; Tassi et al., 2018; Zhang et al., 2018; Bults et al., 2019). For biotransformation studies, however, intact mass analysis is the most favorable MS approach. It is the ideal tool to capture differences in the two-dimensional protein structure of parent biologic and biotransformation products. Therefore, it is of paramount importance to have access to reliable methods to enrich and purify biologics from complex biologic matrices.

For certain molecule classes, generic capture reagents are available. Polyethylene glycol (PEG) modified therapeutic proteins or peptides might be specifically extracted by their PEG domain, using commercially available anti-PEG antibodies. Particularly for therapeutic monoclonal antibodies and Fc fusion proteins, a variety of generic commercially available options is available that capture the Igs via common regions in the $\mathrm{Fc}$ or Fab domain, for example, protein A, G, G/A, L or anti-Fc, anti- $\lambda$ or anti- $\kappa$ capture antibodies. Proteins A, G, and L often are directly conjugated to a purification matrix (e.g., sepharose or magnetic beads), whereas capture antibodies are conjugated to biotin for streptavidin-mediated purification (Fig. 4). However, these approaches are limited by the fact that endogenous Igs are coenriched. For more specific enrichment of the (human/ized) monoclonal antibody from preclinical samples, use of anti-human $\mathrm{IgG}$ (the common isotype of therapeutic monoclonal antibodies) antibodies has been applied successfully for biotransformation studies (Hall et al., 2010; Zell et al., 2016; Kang et al., 2017), and some of them even enable selective enrichment of human IgGs from nonhuman primate samples (Stubenrauch et al., 2009, 2010, 2013).
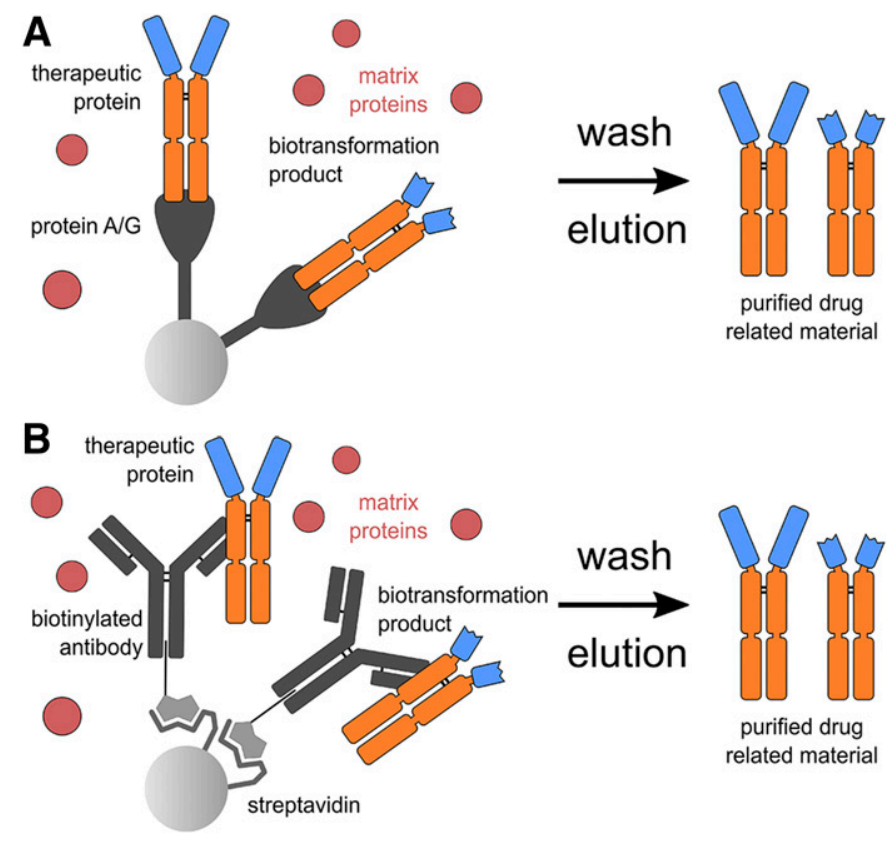

Fig. 4. Schematic representation of therapeutic protein immune capture from a biologic matrix. (A) Fc-specific protein A or $\mathrm{G}$ is used to purify the therapeutic protein and to remove unwanted matrix proteins that would interfere with downstream detection methods. (B) Analogous approach using biotinylated capture antibodies specific against the therapeutic protein and purification by biotinstreptavidin interaction.

The extraction from human samples is significantly more challenging and requires drug-specific reagents. For therapeutic mAbs, anti-idiotypic antibodies or the recombinantly expressed ligands are options. Such reagents are typically generated for ligand-binding assay-based bioanalysis and thus are often available. However, to fully leverage synergies between bioanalysis and biotransformation activities, it is highly recommended to already align at an early project stage. One critical point is the availability of sufficient reagent amounts because the extraction procedures for biotransformation studies require significantly more reagent than for ligand-binding assay. Another critical point is to evaluate whether the bioanalytical reagents really fulfill the requirements for biotransformation analysis. These drug-specific reagents are commonly used for target capture assays to determine the free/active or target-binding competent drug concentrations (Lee et al., 2011; Heinrich et al., 2015). Thus, all drug molecules that are not target-binding competent, for example, due to being complexed by a soluble target, by anti-drug antibodies, or by biotransformation, are not extracted and thus evade analysis. Biotransformation studies require a true total drug extraction (Heinrich et al., 2015), thus a method that really extracts all drug species, particularly the modified ones. For drugs complexed by soluble ligand or anti-drug antibodies, a dissociation step to liberate the drug might be required (Kelley et al., 2013). A very high recovery of the method and evidence that the extraction step does not impact the biotransformation pattern of the compound is at least a good first indicator for the suitability of the method.

A particular challenge for enrichment methods for biotransformation studies is the potential risk that the biotransformation/s itself leads to a loss of extractability. This could happen if the epitope that is recognized by the extraction reagent is modified or the modification of the molecule results in a loss of interaction between the drug and the capture reagent. As an example, deamidation within the complementarity-determining region might result in a loss of binding activity (Yan et al., 2009; Bults et al., 2016; Liu et al., 2018). In such 
a case, the use of a target capture approach, which might be perfect for bioanalytical purposes to monitor active drug, might not be suitable for biotransformation procedures because the modified drug would not bind and thus would not be extractable and finally detectable by the mass spectrometric analysis.

To minimize the potential risk, that a biotransformation event happens exactly at the site of reagent binding, it is advisable to apply a kind of multiepitope approach. From theoretical considerations, the use of polyclonal antibody preparations should be advantageous over the use of a single monoclonal antibody because multiple epitopes of the drug would be detected. This significantly reduces the risk that a biotransformation product is not extracted because only molecules that are modified at all different epitopes are not extractable. Other approaches could be the use of mixtures of monoclonal antibodies that bind the analyte at different domains. Furthermore, the combination of specific reagents with generic reagents could be considered. The availability of reagents to capture drug at different domains is particularly important for fusion proteins and the rising number of multidomain biologics. For those types of compounds, the question of structural integrity and stability of used linkers between the different domains is critical. A differentiated analysis and comparison after independent extractions of the drug and potential biotransformation products via the different domains allow the detection of potential cleavages and loss of domains as well as the identification of the cleavage sites.

Whereas the analytical toolbox is quite large to support preclinical studies, the availability of multiple drug-specific reagents to extract therapeutic proteins from human samples is rather limited. In many cases, the bioanalytical reagents are available. To expand the analytical possibilities in the field of biotransformation studies, it is advisable to already plan reagent generation at an early stage, taking the bioanalytical and biotransformation aspects in mind.

In the case of lack of any suitable extraction procedure, the introduction of specific tags that enable tag-specific extraction is conceivable, however, with the limitation that this modification might influence the biotransformation pathways of the actual drug.

\section{Separation}

The physical separation of parent and biotransformation products is the prerequisite for radiometric detection and quantification and significantly facilitates mass spectrometric identification of biotransformation products. Several chromatographic methods are available to separate proteins (Fig. 5). Ideally, the method should be selective for biotransformation products, and the buffer system should be compatible with LC-MS (Bults et al., 2019).

The most commonly used chromatographic method in intact protein analysis is reverse-phase (RP) chromatography (Damen et al., 2009). Often based on $\mathrm{C} 4, \mathrm{C} 8$, or polyphenylic stationary phases, RP columns separate by hydrophobic properties of the molecules. By increasing the organic solvent concentration in the mobile phase over time, molecules with increasing hydrophobicity elute from the column at later retention time. Depending on the nature of the biotransformation, RPLC is suited for small to large molecular changes. However, if the biotransformation product has similar hydrophobic properties as the parent, there will be little separation. Peptides are usually separated by RP as well, relying on C18 or monolithic stationary phases. Often, nano-flow HPLC is the method of choice, due to the increased MS sensitivity.

Highly orthogonal to RPLC is hydrophilic interaction chromatography, in which analytes are retained on a hydrophilic stationary phase and gradually eluted with decreasing organic solvent concentration. This method has provided application to the intact mass characterization of highly polar glycoproteins (Dominguez-Vega et al., 2018).
Another widely distributed method is size exclusion chromatography (SEC), in which proteins are separated by their migration time on a porous material (Muneeruddin et al., 2014). In general, large molecules migrate faster through a SEC column than small molecules. Most common buffer systems rely on phosphate salts. However, for MS analysis, the buffers that cover acidic to neutral $\mathrm{pH}$ mainly consist of ammonium salts (ammonium carbonate, ammonium hydroxide, ammonium formate, or ammonium acetate), which are volatile and therefore MS compatible. The key parameters are selection of the appropriate buffer system and separation range of the column. The samples can be measured under either denatured or native conditions to address degradation, large fragments, aggregates, or protein complex formation. The relatively low separation power for size difference below $10 \mathrm{kDa}$ limits the use of SEC, if the investigated biotransformation events are truncations of a few amino acids or small changes in the posttranslational modification pattern. SEC is not sensitive enough to clearly separate such events.

A powerful separation method is ion exchange chromatography (IEX), in which molecules are separated by their net charge. IEX enables charge variant analysis (CVA) and relies on gradients of either increasing salt concentration or $\mathrm{pH}$. As nonvolatile salt should be avoided with MS analysis, many $\mathrm{pH}$ buffers consisting of metallic salts cannot be used. CVA has been reported to separate small molecular differences in proteins, such as deamidation, glycation, glycosylation patterns, amino acid substations, or truncations (Vlasak and Ionescu, 2008). To date, nonvolatile salts in the buffers limited the use of IEX with MS. Recently, successful approaches to make CVA compatible with MS have been reported, in which volatile ammonium salts have been used (Füssl et al., 2018, 2019). The challenge that the authors faced was the poor buffering capacity of ammonium salts at $\mathrm{pH}$ around the isoelectric point of the analytes. This led to poor separation in the elution window of many mAbs. To overcome this issue, careful online monitoring of the $\mathrm{pH}$ value during gradient optimization is needed. Another major limitation to date is the extreme sample amount of 50 to $100 \mu \mathrm{g}$ protein. Unless further method development is able to reduce this to the ng scale, for example by using capillary flow columns, CVA-LCMS is of limited usefulness for biotransformation studies.

CVA can also be addressed by a nonchromatographic separation method for charge variants: capillary electrophoresis (CE). In CE, molecules are separated in an electrical field within a capillary containing background electrolytes. CE coupled to MS (CE-MS) had been established a long time ago as well; however, lacking commercial solutions especially in the field of intact protein MS has prevented it from being widely used today. Nevertheless, there has been a successful application of CE-MS to the study of biotransformation of a therapeutic antibody (Han et al., 2017), demonstrating the feasibility of the approach. The major advantages of CE-MS are the extremely low flow rates in the range of nanoliters per minute, the low amounts of sample needed, and the ability to separate by charge variants, which are not trivial to address with HPLC (see above). Similar to CVA-LC-MS, the buffers and capillaries can only contain volatile components to prevent interference with the ionization and transition to gas phase. Recently, fully instrument-independent and integrated, sheathless CE-electrospray ionization-MS systems have become commercially available, which could establish this complimentary separation method in biotransformation groups as a powerful analytics tool (Gahoual et al., 2013; Zhang et al., 2017).

\section{HPLC Radiometric Detection}

The advantage of radioactive labeling in therapeutic protein biotransformation studies is the ability to clearly differentiate drug-related 


\section{Separation}
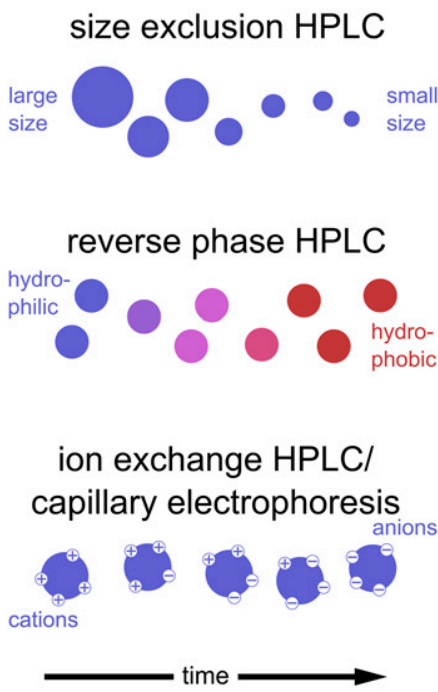

\section{Detection}

radio-HPLC
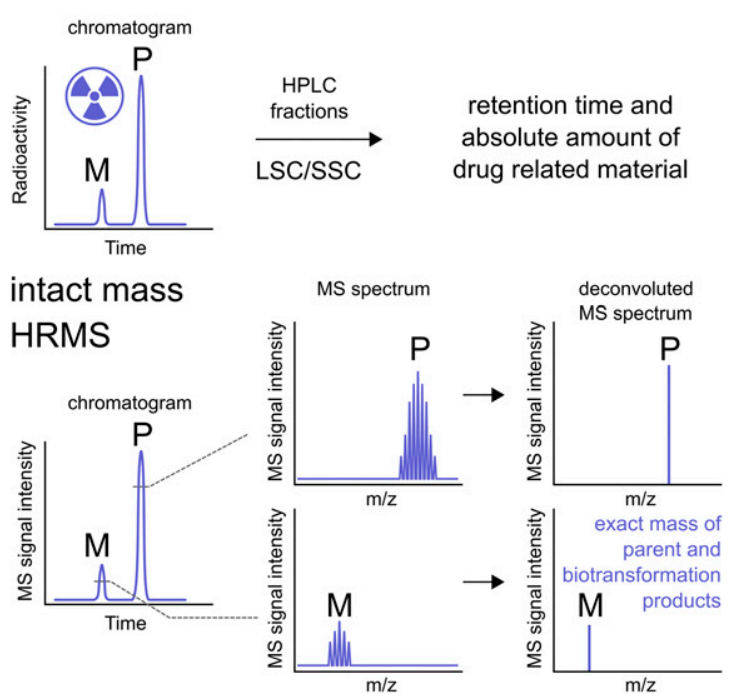

Fig. 5. Overview of separation and detection methods for protein biotransformation analysis. from biologic material derived from the endogenous matrix. A widely used option is the pairing of radiometric detection with HPLC. The therapeutic protein and potential biotransformation products are separated by an inherent physico-chemical property, such as hydrophobicity, isoelectric point, or hydrodynamic radius. The separation power of the chosen HPLC method determines the resolution and specificity of the biotransformation product profile. A major challenge remains that biotransformation products of biologics frequently show similar chromatographic behavior and are difficult to separate. For example, a proteolytic cleavage of two terminal amino acids will not change the $\mathrm{pI}$, size, or hydrophobicity of a molecule sufficiently to observe a different retention time.

Detection is usually carried out by scintillation counting, either by an online radio detector attached to the HPLC or by fraction collection into special scintillator-coated well plates. The former is based on the principle of liquid scintillation counting, in which the scintillator is provided as a cocktail of different solvents and phosphorescent compounds that emit light when excited by ionizing radiation. In the well plate format, the solid scintillator coating is applied to the bottom of the well. This approach is referred to as solid scintillation counting. The main advantages of solid scintillation counting over liquid scintillation counting are higher sensitivity and avoidance of liquid radioactive waste. Recently, technological advances in accelerator MS and cavity ring down spectroscopy measurement of ${ }^{14} \mathrm{C}$-labeled proteins unlocked an unprecedented level of sensitivity that might help to characterize the biotransformation products of biologics (van Duijn et al., 2014; McCartt et al., 2016; Kratochwil et al., 2018). Their application to biotransformation studies has yet to be established, however.

\section{Mass Spectrometry}

This section discusses the use of LC-MS for the detection of biotransformation in therapeutic proteins. To maximize the coverage of molecular changes imposed by biotransformation, it is often required to combine complementary LC-MS techniques. The most straightforward approach is intact mass analysis of proteins. HRMS is the method of choice for intact protein analysis because it allows the measurement at high mass to charge ratio $(\mathrm{m} / \mathrm{z})$ while maintaining a mass accuracy below $5 \mathrm{ppm}$. This key feature is essential to resolve the individual charge states of the protein and allow deconvolution to the exact mass. The characterization of small mass differences within a protein sample is possible and allows the identification of proteoforms or biotransformation products.

The two most prominent mass analyzer types with these specifications are time of flight $(\mathrm{ToF})$ and Fourier transform ion traps, such as the Fourier transform ion cyclotron resonance (FT-ICR) and the Orbitrap. ToF analyzers infer $\mathrm{m} / \mathrm{z}$ by the time ions travel through a defined distance in space, and detection is performed by a microchannel plate detector and an electron multiplier. In contrast, FT-ICR and Orbitraps detect the oscillation of ions in a magnetic (ICR) or electric field (Orbitrap) and derive the $\mathrm{m} / \mathrm{z}$ of all trapped ions simultaneously. The ions are detected by Fourier transformation of the induced ion resonance frequency.

The key features for successful measurement of small $\mathrm{m} / \mathrm{z}$ changes in proteins are resolving power $(\mathrm{R})$, scan speed, and mass range. The prioritization of these parameters will decide which mass analyzer is best suited to fit the biotransformation study goals. $\mathrm{R}$ is defined at a specific $\mathrm{m} / \mathrm{z}$ value and derived by a given method, most commonly by full width at half maximum. FT-ICR offers the highest $\mathrm{R}$ among the discussed mass analyzers $(\mathrm{R}>1,000,000)$, followed by the Orbitrap (up to $\mathrm{R}=$ 500,000 ) and ToF (up to 800,000). $\mathrm{R}$ increases specificity and becomes important when the analyte is measured in a complex matrix with coeluting background molecules. Unfortunately, the FT-ICR mass analyzers lack sensitivity in higher mass ranges where intact proteins are measured. Instruments with application to intact proteins require very high magnetic field strength, which is available only in the most advanced and therefore expensive commercial FT-ICR mass analyzers currently available (Jin et al., 2019). However, a potentially promising application to biotransformation studies is $\mathrm{N}$ - and $\mathrm{C}$-terminal sequence mapping of therapeutic proteins. The technical feasibility of matrixassisted laser desorption/ionization-FT-ICR sequencing with in-source decay fragmentation has been demonstrated (Asakawa et al., 2013). In combination with on-tissue digestion, matrix-assisted laser desorption/ ionization-FT-ICR also provides an interesting platform for MS imaging of proteins (Cillero-Pastor and Heeren, 2014), although its application to biotransformation studies has yet to be established.

In affinity-purified samples, the provided resolution of ToF and Orbitrap instruments is sufficient to address intact protein biotransformation. 
Sensitivity, scan speed, and mass range become more important parameters. Until recently, $\mathrm{m} / \mathrm{z}$ ranges beyond 8000 where the exclusive domain of ToF instruments. With the launch of the Q Exactive ultra-high mass range, Orbitrap mass analyzers are capable of measuring up to $80,000 \mathrm{~m} / \mathrm{z}$. High mass ranges are useful if proteins are measured in their native conformation, at inherently lower charge states, which for a $\mathrm{mAb}$ means $\mathrm{m} / \mathrm{z}$ values about 6000. Extreme mass range might become interesting in future modalities involving mega-dalton protein complexes or virus particles.

ToF instruments, in general, have faster scan speeds than Orbitrap instruments. This can be of advantage in combination with HPLC or CE separation methods, in which the analysis time is limited by the retention or migration time. Faster scan speed allows more data points across the analytic peak. However, lower resolution $(\mathrm{R}>20,000)$ modes of the Orbitrap allow similar speeds with comparable R. Altogether, ToF and Orbitrap instruments are ideally suited for intact protein analysis and are generally well supported by vendor software to support biopharma applications.

\section{Sample Preparation to Facilitate MS Analysis}

An effective way to reduce the size of the analyte is through proteolytic cleavage. Depending on the specificity of the protease, fragments of different size can be achieved. Enzymes like IdeS (An et al., 2014), IdeZ (Lannergard and Guss, 2006), or IgdE (Spoerry et al., 2016) cleave IgG molecules at specific sites around the hinge region, splitting them into Fab and Fc fragments. They are useful tools to dissect antibodies into smaller and less complex molecules to analyze by MS and have been successfully applied to characterize IgGs (Chevreux et al., 2011; Lynaugh et al., 2013; An et al., 2014).

A complimentary approach to intact mass analysis is the complete digestion of proteins into peptides by using site-specific proteases. By far the most popular enzyme for this task is trypsin, as tryptic peptides are ideal for mass spectrometric analysis. The specific cleavage after the primary amine-carrying residues lysine and arginine results in mostly doubly to triply positive charged ions at acidic $\mathrm{pH}$. These much easier to analyze peptide ions still retain substantial information about molecular composition of the intact molecule and can cover subtle changes in a more sensitive and specific manner. For example, deamidation of asparagine and glutamine results in a mass difference of 1 , which is impossible to see on an intact protein level by MS. There are several good examples of using either method or combining intact and proteolytic analysis to address biotransformation in large molecules (Hager et al., 2013; Zell et al., 2016; Kang et al., 2017; Yao et al., 2018).

Glycosylated proteins represent a particularly difficult class of molecules to analyze by MS both in intact and digested methods. This is especially true for heterogeneous glycosylated proteins with typically very similar chromatographic properties, which result in difficult to interpret spectra. Similar to proteases, glycosidases can be used to reduce the heterogeneity of such a molecule by cutting away the glycosylation on the protein. For $\mathrm{N}$-glycosylation the most prominent enzyme is PNGase F. Unfortunately, O-glycosylation lacks an efficient universal enzyme, and a customized deglycosylation mixture of various glycosidases has to be used instead. By separating the glycans from the protein, intact mass analysis becomes much easier. However, if the investigated biotransformation happens to be in the glycosylated region or on the glycans themselves, this approach would be too harsh. Instead, IgG-specific proteases, as discussed above, could also in this study help to partially reduce the heterogeneity without losing too much information.

For more details, the interested reader is referred to several excellent reviews on mass spectrometric analysis of proteins (Katsila et al., 2012; Qu et al., 2017; Bults et al., 2019b).
To detect biotransformation products, innovative strategies have emerged through derivatization of proteolytic cleavage sites. If proteases in the biologic matrix hydrolyze proteins, they create novel, nongenomeencoded $\mathrm{N}$ and $\mathrm{C}$ termini. By chemically attaching a label to these neotermini, the exact cleavage sites on protease substrates can be localized by MS. Conceptually this idea was taken from discovery proteomics research, which successfully employed similar strategies to study protease activities in complex biologic samples (Xu et al., 2009; Chen et al., 2017). By prior protection of free amines in the side chains and the actual protein $\mathrm{N}$ terminus (or by choosing very site-selective reagents that are not reactive with lysine side chains), newly created $\mathrm{N}$ termini can be labeled or even tagged with a biotin group for further enrichment. For $\mathrm{C}$ termini, a similar approach has been reported using enzymatic derivatization with a biotin label (Xu et al., 2011). These are interesting concepts to follow the fate of biologics in vitro and in vivo and already have been used to study therapeutic protein biotransformation (Kullolli et al., 2017).

\section{Conclusions and Future Perspective}

Are biotransformation studies of therapeutic proteins needed? The answer is both yes and no. In the context of safety and efficacy, biotransformation studies are not required for therapeutic proteins by default, and, as long as no unusual PK behavior is observed and the PK/ PD relationship is understood, there is no reason to embark on biotransformation studies. Although all therapeutic proteins are ultimately cleared by degradation to small peptides and individual amino acids, only a subset of therapeutic proteins is subject to biotransformation, leading to circulating biotransformation products. Therefore, these studies are also not required as part of submission packages by regulatory agencies on a routine base (ICH, 2012).

Nevertheless, in case a therapeutic protein is biotransformed, elucidation of biotransformation products can be crucially important. Biotransformation products may or may not be active, and this needs to be taken into account when establishing a PK/PD relationship. The presence of biotransformation products also impacts the bioanalytical strategy, which might be adapted as a consequence to quantify the intact therapeutic protein as well as pharmacologically active biotransformation products.

For the future of biotransformation studies for therapeutic proteins, we see a high need to address these questions early during lead optimization of noncanonical protein formats, ideally using in vitro systems that allow for interspecies comparison as well as for human in vivo prediction early on. Identifying such systems, however, currently remains a major challenge. One key requirement would be that such in vitro systems allow screening of therapeutic proteins with a reasonable sensitivity, throughput, and speed to enable the assessment and ranking of drug candidates. For this, a better understanding of the enzymes involved in the biotransformation reactions of therapeutic proteins would be highly desirable, to enable selection of appropriate cell types and/or plasma/ serum, subfractions, or even (a set of) individual enzymes, which are significantly more active than cellular systems (Schadt et al., 2019). Another limiting factor to a higher throughput of biotransformation studies for therapeutic proteins are the complex analytical strategies, which are much more labor-intense, time-consuming, and complex compared with small molecules. One current gap in this study are software tools dedicated to therapeutic protein biotransformation studies because currently available software options for proteins are optimized rather on $\mathrm{CMC}$ or on proteomics applications.

With more and more antibody candidates with next-generation formats like bispecific antibodies and immunocytokines in the pipelines of pharmaceutical companies, we expect the topic of therapeutic protein 
biotransformation to be rapidly growing, with hopefully many more case studies being shared via publications in the near future.

\section{Acknowledgments}

We thank Sara Belli, Michael Otteneder, and Ruben Alvarez Sanchez for valuable discussions and Russell Jones for careful reading of the manuscript. We express gratitude to two excellent reviewers, who gave valuable input to this manuscript.

\section{Authorship Contributions}

Wrote or contributed to the writing of the manuscript: Schadt, Hauri, Lopes, Edelmann, Staack, Villaseñor, Kettenberger, Roth, Schuler, Richter, Funk.

\section{References}

Akilesh S, Christianson GJ, Roopenian DC, and Shaw AS (2007) Neonatal FcR expression in bone marrow-derived cells functions to protect serum IgG from catabolism. J Immunol 179: $4580-4588$.

Alessandri L, Ouellette D, Acquah A, Rieser M, Leblond D, Saltarelli M, Radziejewski C, Fujimori $\mathrm{T}$, and Correia I (2012) Increased serum clearance of oligomannose species present on a human IgG1 molecule. MAbs 4:509-520.

Amartey JK, Esguerra C, Al-Otaibi B, Al-Jammaz I, Al-Qahtani M, and Parhar RS (2005) Prosthetic radioiodination of interleukin-8 ([(123/131)]-IL-8): biological behavior in a mouse infection model. Appl Radiat Isot 62:39-47.

An Y, Zhang Y, Mueller HM, Shameem M, and Chen X (2014) A new tool for monoclonal antibody analysis: application of IdeS proteolysis in IgG domain-specific characterization. MAbs 6:879-893.

Asakawa D, Calligaris D, Zimmerman TA, and De Pauw E (2013) In-source decay during matrixassisted laser desorption/ionization combined with the collisional process in an FTICR mass spectrometer. Anal Chem 85:7809-7817.

Beck A and Reichert JM (2011) Therapeutic Fc-fusion proteins and peptides as successful alternatives to antibodies. MAbs 3:415-416.

Beck A and Reichert JM (2014) Antibody-drug conjugates: present and future. MAbs 6:15-17.

Bolton AE and Hunter WM (1973) The labelling of proteins to high specific radioactivities by conjugation to a 125I-containing acylating agent. Biochem J 133:529-539.

Boswell CA, Tesar DB, Mukhyala K, Theil FP, Fielder PJ, and Khawli LA (2010) Effects of charge on antibody tissue distribution and pharmacokinetics. Bioconjug Chem 21:2153-2163.

Brinkmann U and Kontermann RE (2017) The making of bispecific antibodies. MAbs 9:182-212.

Brix K (2013) Proteases Structure and Function, Springer, Wien.

Brix K, Dunkhorst A, Mayer K, and Jordans S (2008) Cysteine cathepsins: cellular roadmap to different functions. Biochimie 90:194-207.

Bults P, Bischoff R, Bakker H, Gietema JA, and van de Merbel NC (2016) LC-MS/MS-based monitoring of in vivo protein biotransformation: quantitative determination of trastuzumab and its deamidation products in human plasma. Anal Chem 88:1871-1877.

Bults P, Spanov B, Olaleye O, van de Merbel NC, and Bischoff R (2019) Intact protein bioanalysis by liquid chromatography - high-resolution mass spectrometry. J Chromatogr B Analyt Technol Biomed Life Sci 1110-1111:155-167.

Cai B, Pan H, and Flynn GC (2011) C-terminal lysine processing of human immunoglobulin G2 heavy chain in vivo. Biotechnol Bioeng 108:404-412.

Carter PJ and Lazar GA (2018) Next generation antibody drugs: pursuit of the 'high-hanging fruit.' Nat Rev Drug Discov 17:197-223.

Challa DK, Wang X, Montoyo HP, Velmurugan R, Ober RJ, and Ward ES (2019) Neonatal Fc receptor expression in macrophages is indispensable for IgG homeostasis. MAbs 11:848-860.

Chen D, Disotuar MM, Xiong X, Wang Y, and Chou DH (2017) Selective N-terminal functionalization of native peptides and proteins. Chem Sci (Camb) 8:2717-2722.

Chen X, Liu YD, and Flynn GC (2009) The effect of Fc glycan forms on human IgG2 antibody clearance in humans. Glycobiology 19:240-249.

Chevreux G, Tilly N, and Bihoreau N (2011) Fast analysis of recombinant monoclonal antibodies using IdeS proteolytic digestion and electrospray mass spectrometry. Anal Biochem $\mathbf{4 1 5}$ 212-214.

Cillero-Pastor B and Heeren RM (2014) Matrix-assisted laser desorption ionization mass spectrometry imaging for peptide and protein analyses: a critical review of on-tissue digestion. J Proteome Res 13:325-335.

Cilliers C, Nessler I, Christodolu N, and Thurber GM (2017) Tracking antibody distribution with near-infrared fluorescent dyes: impact of dye structure and degree of labeling on plasma clearance. Mol Pharm 14:1623-1633.

Conner KP, Rock BM, Kwon GK, Balthasar JP, Abuqayyas L, Wienkers LC, and Rock DA (2014) Evaluation of near infrared fluorescent labeling of monoclonal antibodies as a tool for tissue distribution. Drug Metab Dispos 42: 1906-1913.

Cymer F, Thomann M, Wegele H, Avenal C, Schlothauer T, Gygax D, and Beck H (2017) Oxidation of M252 but not M428 in hu-IgG1 is responsible for decreased binding to and activation of hu-FcyRIIa (His131). Biologicals 50:125-128.

Damen CW, Derissen EJ, Schellens JH, Rosing H, and Beijnen JH (2009) The bioanalysis of the monoclonal antibody trastuzumab by high-performance liquid chromatography with fluorescence detection after immuno-affinity purification from human serum. J Pharm Biomed Anal 50 $861-866$.

Deacon CF (2004) Circulation and degradation of GIP and GLP-1. Horm Metab Res 36:761-765. Domínguez-Vega E, Tengattini S, Peintner C, van Angeren J, Temporini C, Haselberg R, Massolin G, and Somsen GW (2018) High-resolution glycoform profiling of intact therapeutic proteins by hydrophilic interaction chromatography-mass spectrometry. Talanta 184:375-381

Duggan JX (2018) Progress in high-sensitivity hybrid LC-MS/MS methods for the bioanalysis of protein drugs and performance tests for their validation. Bioanalysis 10:983-986.

Edelmann MR, Kettenberger H, Knaupp A, Schlothauer T, and Otteneder MB (2019) Radiolabeled IgG antibodies: impact of various labels on neonatal $\mathrm{Fe}$ receptor binding. J Labelled Comp Radiopharm DOI: $10.1002 /$ jlcr.3793 [published ahead of print].
EMA (2007) Guideline on the Clinical Investigation of the Pharmacokinetics of Therapeutic Proteins, European Medicines Agency, Amsterdam, Netherlands.

FDA (2016) Guidance for Industry: Safety Testing of Drug Metabolites, US Department of Health and Human Services FaDA, Center for Drug Evaluation and Research, Silver Spring, MD.

Flygare JA, Pillow TH, and Aristoff P (2013) Antibody-drug conjugates for the treatment of cancer. Chem Biol Drug Des 81:113-121.

Fraker PJ and Speck JC Jr (1978) Protein and cell membrane iodinations with a sparingly soluble chloroamide, 1,3,4,6-tetrachloro-3a,6a-diphrenylglycoluril. Biochem Biophys Res Commun 80: 849-857.

Füssl F, Cook K, Scheffler K, Farrell A, Mittermayr S, and Bones J (2018) Charge variant analysis of monoclonal antibodies using direct coupled $\mathrm{pH}$ gradient cation exchange chromatography to high-resolution native mass spectrometry. Anal Chem 90:4669-4676.

Füssl F, Trappe A, Cook K, Scheffler K, Fitzgerald O, and Bones J (2019) Comprehensive characterisation of the heterogeneity of adalimumab via charge variant analysis hyphenated online to native high resolution Orbitrap mass spectrometry. MAbs 11:116-128.

Gahoual R, Burr A, Busnel JM, Kuhn L, Hammann P, Beck A, François YN, and Leize-Wagner E (2013) Rapid and multi-level characterization of trastuzumab using sheathless capillary electrophoresis-tandem mass spectrometry. MAbs 5:479-490.

Geiger T and Clarke S (1987) Deamidation, isomerization, and racemization at asparaginyl and aspartyl residues in peptides: succinimide-linked reactions that contribute to protein degradation. $J$ Biol Chem 262:785-794.

Goetze AM, Liu YD, Arroll T, Chu L, and Flynn GC (2012) Rates and impact of human antibody glycation in vivo. Glycobiology 22:221-234.

Greenwood FC, Hunter WM, and Glover JS (1963) The preparation of I-131-labelled human growth hormone of high specific radioactivity. Biochem J 89:114-123.

Hager T, Spahr C, Xu J, Salimi-Moosavi H, and Hall M (2013) Differential enzyme-linked immunosorbent assay and ligand-binding mass spectrometry for analysis of biotransformation of protein therapeutics: application to various FGF21 modalities. Anal Chem 85:2731-2738.

Hall MP (2014) Biotransformation and in vivo stability of protein biotherapeutics: impact on candidate selection and pharmacokinetic profiling. Drug Metab Dispos 42:1873-1880.

Hall MP, Gegg C, Walker K, Spahr C, Ortiz R, Patel V, Yu S, Zhang L, Lu H, DeSilva B, et al. (2010) Ligand-binding mass spectrometry to study biotransformation of fusion protein drugs and guide immunoassay development: strategic approach and application to peptibodies targeting the thrombopoietin receptor. AAPS $J$ 12:576-585.

Han M, Pearson JT, Wang Y, Winters D, Soto M, Rock DA, and Rock BM (2017) Immunoaffinity capture coupled with capillary electrophoresis - mass spectrometry to study therapeutic protein stability in vivo. Anal Biochem 539:118-126.

He J, Su D, Ng C, Liu L, Yu SF, Pillow TH, Del Rosario G, Darwish M, Lee BC, Ohri R, et al (2017) High-resolution accurate-mass mass spectrometry enabling in-depth characterization of in vivo biotransformations for intact antibody-drug conjugates. Anal Chem 89:5476-5483.

Heinrich J, Staack RF, Stubenrauch KG, and Papadimitriou A (2015) Proposal for a harmonized descriptive analyte nomenclature for quantitative large-molecule bioanalysis. Bioanalysis 7: 3057-3062.

Hempel K (1963) [On a new radioautographic method in the histochemical determination of protein-bound sulfhydryl groups with tritiated N-phenyl-maleimide]. Exp Cell Res 31:594-596. Hermanson GT (2013) Bioconjugate Techniques, Elsevier, Amsterdam.

Hmiel LK, Brorson KA, and Boyne MT II (2015) Post-translational structural modifications of immunoglobulin G and their effect on biological activity. Anal Bioanal Chem 407:79-94.

Hortin GL and Sviridov D (2010) The dynamic range problem in the analysis of the plasma proteome. J Proteomics 73:629-636.

Huotari J and Helenius A (2011) Endosome maturation. EMBO J 30:3481-3500.

Hutmacher C and Neri D (2019) Antibody-cytokine fusion proteins: biopharmaceuticals with immunomodulatory properties for cancer therapy. Adv Drug Deliv Rev 141:67-91.

ICH (2009) S9 Nonclinical Evaluation for Anticancer Pharmaceuticals, The International Council for Harmonisation of Technical Requirements for Pharmaceuticals for Human Use, Geneva, Switzerland

ICH (2010) M3(R2) Nonclinical Safety Studies for the Conduct of Human Clinical Trials and Marketing Authorization for Pharmaceuticals, The International Council for Harmonisation of Technical Requirements for Pharmaceuticals for Human Use (ICH), Geneva, Switzerland.

ICH (2012) ICH S6 (RI) Preclinical Safety Evaluation of Biotechnology-Derived Pharmaceuticals, The International Council for Harmonisation of Technical Requirements for Pharmaceuticals for Human Use (ICH), Geneva, Switzerland.

Jaramillo CAC, Belli S, Cascais AC, Dudal S, Edelmann MR, Haak M, Brun ME, Otteneder MB, Ullah M, Funk C, et al. (2017) Toward in vitro-to-in vivo translation of monoclonal antibody pharmacokinetics: application of a neonatal $\mathrm{Fc}$ receptor-mediated transcytosis assay to understand the interplaying clearance mechanisms. MAbs 9:781-791.

Jin W, Burton L, and Moore I (2018) LC-HRMS quantitation of intact antibody drug conjugate trastuzumab emtansine from rat plasma. Bioanalysis 10:851-862.

Jin Y, Lin Z, Xu Q, Fu C, Zhang Z, Zhang Q, Pritts WA, and Ge Y (2019) Comprehensive characterization of monoclonal antibody by Fourier transform ion cyclotron resonance mass spectrometry. MAbs 11:106-115.

Kang L, Camacho RC, Li W, D'Aquino K, You S, Chuo V, Weng N, and Jian W (2017) Simultaneous catabolite identification and quantitation of large therapeutic protein at the intact level by immunoaffinity capture liquid chromatography-high-resolution mass spectrometry. Anal Chem 89:6065-6075.

Kappelhoff R, Puente XS, Wilson CH, Seth A, López-Otín C, and Overall CM (2017) Overview of transcriptomic analysis of all human proteases, non-proteolytic homologs and inhibitors: organ, tissue and ovarian cancer cell line expression profiling of the human protease degradome by the CLIP-CHIP ${ }^{\mathrm{TM}}$ DNA microarray. Biochim Biophys Acta Mol Cell Res 1864:2210-2219.

Katsila T, Siskos AP, and Tamvakopoulos C (2012) Peptide and protein drugs: the study of their metabolism and catabolism by mass spectrometry. Mass Spectrom Rev 31:110-133.

Kelley M, Ahene AB, Gorovits B, Kamerud J, King LE, McIntosh T, and Yang J (2013) Theoretical considerations and practical approaches to address the effect of anti-drug antibody (ADA) on quantification of biotherapeutics in circulation. AAPS J 15:646-658

Kellie JF and Karlinsey MZ (2018) Review of approaches and examples for monitoring biotransformation in protein and peptide therapeutics by MS. Bioanalysis DOI: 10.4155/bio-20180113 [published ahead of print].

Kontermann RE and Brinkmann U (2015) Bispecific antibodies. Drug Discov Today 20:838-847. 
Kratochwil NA, Dueker SR, Muri D, Senn C, Yoon H, Yu BY, Lee GH, Dong F, and Otteneder MB (2018) Nanotracing and cavity-ring down spectroscopy: a new ultrasensitive approach in large molecule drug disposition studies. PLoS One 13:e205435.

Kullolli M, Rock DA, and Ma J (2017) Immuno-affinity capture followed by TMPP N-terminus tagging to study catabolism of therapeutic proteins. J Proteome Res 16:911-919.

Kummer U (1986) Tritium radiolabeling of antibodies to high specific activity with N-succinimidy [2,3-3H]propionate: use in detecting and analyzing monoclonal antibodies. Methods Enzymol 121:670-678.

Labrijn AF, Janmaat ML, Reichert JM, and Parren PWHI (2019) Bispecific antibodies: a mechanistic review of the pipeline. Nat Rev Drug Discov 18:585-608.

Lannergård J and Guss B (2006) IdeE, an IgG-endopeptidase of Streptococcus equi ssp. equi. FEMS Microbiol Lett 262:230-235.

Lee JW (2013) ADME of monoclonal antibody biotherapeutics: knowledge gaps and emerging tools. Bioanalysis 5:2003-2014.

Lee JW, Kelley M, King LE, Yang J, Salimi-Moosavi H, Tang MT, Lu JF, Kamerud J, Ahene A, Myler H, et al. (2011) Bioanalytical approaches to quantify "total" and "free" therapeutic antibodies and their targets: technical challenges and PK/PD applications over the course of drug development. AAPS J 13:99-110.

Leipold D and Prabhu S (2019) Pharmacokinetic and pharmacodynamic considerations in the design of therapeutic antibodies. Clin Transl Sci 12:130-139.

Li F, Weng Y, Zhang G, Han X, Li D, and Neubert H (2019) Characterization and quantification of an fc-FGF21 fusion protein in rat serum using immunoaffinity LC-MS. AAPS J 21:84

Li Y, Monine M, Huang Y, Swann P, Nestorov I, and Lyubarskaya Y (2016) Quantitation and pharmacokinetic modeling of therapeutic antibody quality attributes in human studies. MAbs 8 1079-1087.

Liu L, Xu K, Li J, Maia M, Mathieu M, Elliott R, Yang J, Nijem I, and Kaur S (2018) Optimizing hybrid LC-MS/MS binding conditions is critical: impact of biotransformation on quantification of trastuzumab. Bioanalysis DOI: 10.4155/bio-2018-0196 [published ahead of print].

Liu YD, Goetze AM, Bass RB, and Flynn GC (2011) N-terminal glutamate to pyroglutamate conversion in vivo for human IgG2 antibodies. J Biol Chem 286:11211-11217.

Lynaugh H, Li H, and Gong B (2013) Rapid Fc glycosylation analysis of Fc fusions with IdeS and liquid chromatography mass spectrometry. MAbs 5:641-645.

McCartt AD, Ognibene TJ, Bench G, and Turteltaub KW (2016) Quantifying carbon-14 for biology using cavity ring-down spectroscopy. Anal Chem 88:8714-8719.

Mentlein R (1999) Dipeptidyl-peptidase IV (CD26)--role in the inactivation of regulatory peptides. Regul Pept 85:9-24

Montoyo HP, Vaccaro C, Hafner M, Ober RJ, Mueller W, and Ward ES (2009) Conditional deletion of the MHC class I-related receptor FcRn reveals the sites of IgG homeostasis in mice. Proc Natl Acad Sci USA 106:2788-2793.

Morrison M (1980) Lactoperoxidase-catalyzed iodination as a tool for investigation of proteins. Methods Enzymol 70:214-220.

Müller GH (1980) Protein labelling with 3H-NSP (N-succinimidyl-[2,3-3H]propionate). J Cell Sci 43:319-328.

Muneeruddin K, Thomas JJ, Salinas PA, and Kaltashov IA (2014) Characterization of small protein aggregates and oligomers using size exclusion chromatography with online detection by native electrospray ionization mass spectrometry. Anal Chem 86:10692-10699.

Pérez-Silva JG, Español Y, Velasco G, and Quesada V (2016) The Degradome database: expanding roles of mammalian proteases in life and disease. Nucleic Acids Res 44:D351-D355.

Qian J, Yearley E, Tian S, Jing L, Balsaraf A, Lo Surdo P, Huang Y, Chandramouli S, Bottomley MJ, Moniotte N, et al. (2018) Non-enzymatic and site-specific glycan shedding: a novel protein degradation pathway observed in a stabilized form of RSV prefusion F protein. Anal Chem $\mathbf{9 0}$ 10897-10902.

Qiu X, Kang L, Case M, Weng N, and Jian W (2018) Quantitation of intact monoclonal antibody in biological samples: comparison of different data processing strategies. Bioanalysis 10 $1055-1067$.

Qu M, An B, Shen S, Zhang M, Shen X, Duan X, Balthasar JP, and Qu J (2017) Qualitative and quantitative characterization of protein biotherapeutics with liquid chromatography mass spectrometry. Mass Spectrom Rev 36:734-754

Richter WF, Christianson GJ, Frances N, Grimm HP, Proetzel G, and Roopenian DC (2018) Hematopoietic cells as site of first-pass catabolism after subcutaneous dosing and contributors to systemic clearance of a monoclonal antibody in mice. MAbs 10:803-813.

Roopenian DC and Akilesh S (2007) FcRn: the neonatal Fc receptor comes of age. Nat Rev Immunol 7:715-725.

Saad OM, Shen BQ, Xu K, Khojasteh SC, Girish S, and Kaur S (2015) Bioanalytical approaches for characterizing catabolism of antibody-drug conjugates. Bioanalysis 7:1583-1604

Sanman LE, van der Linden WA, Verdoes M, and Bogyo M (2016) Bifunctional probes of cathepsin protease activity and $\mathrm{pH}$ reveal alterations in endolysosomal $\mathrm{pH}$ during bacteria infection. Cell Chem Biol 23:793-804.

Schadt S, Bister B, Chowdhury SK, Funk C, Hop CECA, Humphreys WG, Igarashi F, James AD, Kagan M, Khojasteh SC, et al. (2018) A decade in the MIST: learnings from investigations of drug metabolites in drug development under the "metabolites in safety testing" regulatory guidance. Drug Metab Dispos 46:865-878.

Schadt S, Husser C, Staack RF, Ekiciler A, Qiu NH, Fowler S, Funk C, and Kratochwil NA (2019) The in vitro biotransformation of the fusion protein tetranectin-apolipoprotein A1. Sci Rep 9 : 4074

Sender R, Fuchs S, and Milo R (2016) Revised estimates for the number of human and bacteria cells in the body. PLoS Biol 14:e1002533.

Spoerry C, Seele J, Valentin-Weigand P, Baums CG, and von Pawel-Rammingen U (2016) Identification and characterization of IgdE, a novel IgG-degrading protease of Streptococcus suis with unique specificity for porcine IgG. J Biol Chem 291:7915-7925.

Stracke J, Emrich T, Rueger P, Schlothauer T, Kling L, Knaupp A, Hertenberger H, Wolfert A, Spick C, Lau W, et al. (2014) A novel approach to investigate the effect of methionine oxidation on pharmacokinetic properties of therapeutic antibodies. MAbs 6:1229-1242.

Stubenrauch K, Wessels U, Essig U, Kowalewsky F, Vogel R, and Heinrich J (2013) Characterization of murine anti-human Fab antibodies for use in an immunoassay for generic quantification of human Fab fragments in non-human serum samples including cynomolgus monkey samples. J Pharm Biomed Anal 72:208-215.

Stubenrauch K, Wessels U, Essig U, Vogel R, and Schleypen J (2010) Evaluation of a generic immunoassay with drug tolerance to detect immune complexes in serum samples from cynomolgus monkeys after administration of human antibodies. J Pharm Biomed Anal 52:249-254

Stubenrauch K, Wessels U, and Lenz H (2009) Evaluation of an immunoassay for human-specific quantitation of therapeutic antibodies in serum samples from non-human primates. J Pharm Biomed Anal 49:1003-1008.

Tack BF, Dean J, Eilat D, Lorenz PE, and Schechter AN (1980) Tritium labeling of proteins to high specific radioactivity by reduction methylation. J Biol Chem 255:8842-8847.

Tarcic G and Yarden Y (2013) Antibody-mediated receptor endocytosis: harnessing the cellular machinery to combat cancer, in Vesicle Trafficking in Cancer pp 361-384, Springer New York, New York, NY.

Tassi M, De Vos J, Chatterjee S, Sobott F, Bones J, and Eeltink S (2018) Advances in native highperformance liquid chromatography and intact mass spectrometry for the characterization of biopharmaceutical products. J Sep Sci 41:125-144.

Tumey LN, Rago B, and Han X (2015) In vivo biotransformations of antibody-drug conjugates. Bioanalysis 7:1649-1664.

Vaidyanathan G and Zalutsky MR (1990) Protein radiohalogenation: observations on the design of N-succinimidyl ester acylation agents. Bioconjug Chem 1:269-273.

van den Broek I and van Dongen WD (2015) LC-MS-based quantification of intact proteins: perspective for clinical and bioanalytical applications. Bioanalysis 7:1943-1958.

van Duijn E, Sandman H, Grossouw D, Mocking JA, Coulier L, and Vaes WH (2014) Automated combustion accelerator mass spectrometry for the analysis of biomedical samples in the low attomole range. Anal Chem 86:7635-7641

Verhamme IM, Leonard SE, and Perkins RC (2019) Proteases: pivot points in functional proteomics. Methods Mol Biol 1871:313-392.

Vlasak J and Ionescu R (2008) Heterogeneity of monoclonal antibodies revealed by chargesensitive methods. Curr Pharm Biotechnol 9:468-481.

Wall DA and Maack T (1985) Endocytic uptake, transport, and catabolism of proteins by epithelial cells. Am J Physiol 248:C12-C20.

Walsh G (2018) Biopharmaceutical benchmarks 2018. Nat Biotechnol 36:1136-1145.

Wang W, Chen N, Shen X, Cunningham P, Fauty S, Michel K, Wang B, Hong X, Adreani C, Nunes CN, et al. (2012) Lymphatic transport and catabolism of therapeutic proteins after subcutaneous administration to rats and dogs. Drug Metab Dispos 40:952-962.

Wei C, Su D, Wang J, Jian W, and Zhang D (2018) LC-MS challenges in characterizing and quantifying monoclonal antibodies (mAb) and antibody-drug conjugates (ADC) in biological samples. Curr Pharmacol Rep 4:45-63.

Werle M and Bernkop-Schnürch A (2006) Strategies to improve plasma half life time of peptide and protein drugs. Amino Acids 30:351-367.

WHO (2013) Guidelines on the Quality, Safety, and Efficacy of Biotherapeutic Protein Products Prepared by Recombinant DNA Technology, World Health Organization, Geneva, Switzerland.

Wilbur DS (1992) Radiohalogenation of proteins: an overview of radionuclides, labeling methods, and reagents for conjugate labeling. Bioconjug Chem 3:433-470.

Wright HT (1991) Nonenzymatic deamidation of asparaginyl and glutaminyl residues in proteins. Crit Rev Biochem Mol Biol 26:1-52.

$\mathrm{Xu}$ G, Shin SB, and Jaffrey SR (2009) Global profiling of protease cleavage sites by chemoselective labeling of protein N-termini. Proc Natl Acad Sci USA 106:19310-19315.

Xu G, Shin SB, and Jaffrey SR (2011) Chemoenzymatic labeling of protein C-termini for positive selection of C-terminal peptides. ACS Chem Biol 6:1015-1020.

Yan B, Steen S, Hambly D, Valliere-Douglass J, Vanden Bos T, Smallwood S, Yates Z, Arroll T, Han Y, Gadgil H, et al. (2009) Succinimide formation at Asn 55 in the complementarity determining region of a recombinant monoclonal antibody IgG1 heavy chain. J Pharm Sci $\mathbf{9 8}$ 3509-3521.

Yao M, Chen B, Zhao W, Mehl JT, Li L, and Zhu M (2018) LC-MS differential analysis for fast and sensitive determination of biotransformation of therapeutic proteins. Drug Metab Dispos 46: $451-457$.

Yin S, Pastuskovas CV, Khawli LA, and Stults JT (2013) Characterization of therapeutic monoclonal antibodies reveals differences between in vitro and in vivo time-course studies. Pharm Res 30:167-178.

Yu M, Brown D, Reed C, Chung S, Lutman J, Stefanich E, Wong A, Stephan JP, and Bayer R (2012) Production, characterization, and pharmacokinetic properties of antibodies with N-linked mannose-5 glycans. MAbs 4:475-487.

Zell M, Husser C, Staack RF, Jordan G, Richter WF, Schadt S, and Pähler A (2016) In vivo biotransformation of the fusion protein tetranectin-apolipoprotein A1 analyzed by ligand-binding mass spectrometry combined with quantitation by ELISA. Anal Chem 88:11670-11677.

Zhang L, Vasicek LA, Hsieh S, Zhang S, Bateman KP, and Henion J (2018) Top-down LC-MS quantitation of intact denatured and native monoclonal antibodies in biological samples. Bioanalysis 10:1039-1054.

Zhang Q, Schenauer MR, McCarter JD, and Flynn GC (2013) IgG1 thioether bond formation in vivo. $J$ Biol Chem 288:16371-16382.

Zhang S, Raedschelders K, Santos M, and Van Eyk JE (2017) Profiling B-type natriuretic peptide cleavage peptidoforms in human plasma by capillary electrophoresis with electrospray ionization mass spectrometry. J Proteome Res 16:4515-4522.

Zolotarev YA, Dorokhova EM, Nezavibatko VN, Borisov YA, Rosenberg SG, Velikodvorskaia GA, Neumivakin LV, Zverlov VV, and Myasoedov NF (1995) The solid-state catalytic synthesis of tritium labeled amino acids, peptides and proteins. Amino Acids 8:353-365.

Address correspondence to: Dr. Simone Schadt, Roche Pharma Research and Early Development, Pharmaceutical Sciences, Roche Innovation Center Basel, F. Hoffmann-La Roche, Grenzacher Strasse 124, 4070 Basel, Switzerland. E-mail: simone.schadt@roche.com 